\title{
PENGARUH PELATIHAN TERHADAP KINERJA KARYAWAN PT. DAHANA (PERSERO) SUBANG
}

\section{Ine Mariane ${ }^{1}$}

Fakultas Ilmu Sosial dan Ilmu Politik Universitas Pasundan

ine.mariane@unpas.ac.id

\section{Iwan Henri Kusnadi ${ }^{2}$}

Fakultas Ilmu Administrasi Universitas Subang

iwanhenri01@gmail.com

\section{Muhammad Rifqi Baihaqi ${ }^{3}$}

Fakultas Ilmu Administrasi Universitas Subang

baihaqirifqi32@gmail.com

\begin{abstract}
Abstrak
Karyawan sebagai aset perusahaan dengan peranannya yang sangat menentukan berhasil tidaknya perusahaan dalam mencapai tujuannya. Dalam memperoleh karyawan yang berkinerja baik perusahaan harus mengadakan pelaksanaan pelatihan, yang berfungsi untuk meningkatkan kemampuan karyawan dalam bekerja. Penelitian ini dilakukan pada karyawan PT. Dahana (Persero) Subang. Fenomena yang terjadi adalah kinerja yang dihasilkan karyawan masih rendah. Hal tersebut ditandai dengan pencapaian kinerja yang tidak sesuai dengan target, dan kurangnya keterampilan pada karyawan. Penelitian ini bertujuan untuk mengetahui adakah pengaruh pelatihan terhadap kinerja karyawan PT. Dahana (Persero) Subang dan menggunakan metode deskriptif dan kausal dengan sampel berjumlah 66 orang responden dan juga menggunakan bantuan program aplikasi SPSS 18 for windows. Teknik analisis yang digunakan adalah koefisien korelasi pearson product moment dan analisis regresi sederhana. Pengujian hipotesis menggunakan uji t-test untuk melihat pengaruh secara parsial. Hasil penelitian menunjukkan bahwa gambaran pelatihan dan kinerja pada PT. Dahana (Persero) Subang sudah optimal. Pelatihan dan kinerja karyawan PT. Dahana (Persero) Subang memiliki pengaruh dengan koefisien korelasi sebesar 0,251. Kemudian berdasarkan hasil perhitungan R Square atau koefisien determinasi sebesar 6,3,\% memiliki arti bahwa kinerja karyawan PT. Dahana (Persero) Subang dipengaruhi oleh pelatihan sebesar 6,3\%. Penulis merekomendasikan agar perusahaan meningkatkan pemberian program pelatihan guna menunjang kinerja perusahaan.
\end{abstract}

Kata Kunci: Pelatihan, Kinerja Karyawan 


\section{Abstract}

Employees as company assets with a very decisive role the success or failure of the company in reaching agreement. In accepting employees who perform well the company must conduct training, which works to improve the ability of employees to work. This research was conducted on the employees of PT. Dahana (Persero) Subang. The phenomenon that occurs is that the performance produced by employees is still low. This is indicated by the success that is not in accordance with the target, and the lack of skills in employees. This study aims to determine whether there are training objectives on the performance of employees of PT. Dahana (Persero) Subang and uses descriptive and causal methods with a sample across 66 respondents and also using the help of the SPSS 18 application program for windows. The analysis technique used is the Pearson product moment conversion coefficient and simple regression analysis. Hypothesis testing uses $t$-test to see the effect partially. The results showed an overview of training and performance at PT. Dahana (Persero) Subang is optimal. PT. Dahana (Persero) Subang Employee training and performance. PT. Dahana (Persero) Subang has an influence with an interaction coefficient of 0.251 . Then based on the results of the calculation of $R$ Square or the coefficient of determination of 6.3,\% has a meaning about the performance of the employees of PT. Dahana (Persero) Subang was determined by training at $6.3 \%$. The author agrees that the company enhances the assistance program training to support company performance.

Keywords: Training, Employee Performance

\section{Pendahuluan}

Di era globalisasi dan era industri 4.0 saat ini, persaingan antar perusahaan semakin gencar dan teknologi yang maju menimbulkan tantangan perusahaan untuk melakukan perubahaan pada berbagai aspek dalam pengelolaan perusahaan. Menghadapi era globalisasi industri 4.0 dan persaingan baik pada tingkat nasional maupun internasional, maka para karyawan setiap perusahaan harus menghadapi perubahan - perubahan dalam teknologi, seperti munculnya teknologi baru atau metode kerja baru di perusahaan. Situasi seperti ini membuat perusahaan membutuhkan sumber daya manusia yang mempunyai pengetahuan, keterampilan, kemampuan yang mumpuni dan terlatih yang dapat memfokuskan kemampuan mereka pada tugas dan tanggung jawab untuk mencapai tujuan perusahaan. Sumber daya manusia merupakan unsur penting dalam suatu perusahaan, karena unsur ini merupakan bagian yang menggerakkan sistem disebuah perusahaan dalam rangka pencapaian tujuan perusahaan. Sumber daya manusia memiliki andil besar dalam menentukan maju atau mundurnya suatu perusahaan. Dengan ini, perusahaan harus membentuk sumber daya manusia yang berkompeten pada bidangnya, terampil, berwawasan luas, dan terlatih yang dapat memfokuskan kemampuan mereka pada tugas yang diberikan guna mendukung kemajuan perusahaan.

Menurut Nawawi (2001:37), Sumber daya manusia adalah orang-orang yang bekerja dan berfungsi sebagai aset organisasi atau perusahaan yang dapat dihitung jumlahnya (kuantitatif). SDM adalah potensi yang menjadi motor penggerak organisasi yang berbeda dengan sumber daya yang lainnya. Nilai-nilai kemanusiaan 
yag dimilikinya mengharuskan sumber daya manusia diperlukan secara bersamaan dengan sumber daya manusia lainnya.Kinerja merupakan bagian yang sangat penting dan menarik karena terbukti sangat penting manfaatnya. Oleh karena itu kinerja merupakan hasil kerja yang secara kualitas dan kuantitas yang telah dicapai oleh seorang karyawan atau pegawai dalam mengemban tugasnya sesuai dengan tanggung jawab yang telah diberikan kepadanya. Yang dimaksud dengan kualitas di sini adalah dilihat dari segi kebersihan, kehalusan dan ketelitian dalam menjalankan tugas dan pekerjaan nya. Sedangkan, yang dimaksud dengan kuantitas itu dilihat dari banyaknya jumlah pekerjaan yang harus diselesaikan oleh pegawai atau karyawan tersebut menurut Mangkunegara (2001 :67). Sinambela (2011:136), mengemukakan bahwa kinerja pegawai didefinisikan kemampuan pegawai dalam melakukan sesuatu keahlian tertentu. Kinerja pegawai sangatlah perlu, sebab dengan kinerja ini akan diketahui seberapa jauh kemampuan pegawai dalam melaksanakan tugas yang dibebankan kepadanya, sehingga diperlukan penentuan kriteria yang jelas dan terukur serta ditetapkan secara bersama - sama yang dijadikan sebagai acuan.

Kinerja karyawan mempunyai beberapa faktor yang dapat mempengaruhi, salah satu faktor yang mempengaruhi kinerja karyawan adalah pelatihan. Menurut Mathis (2006:301), "Pelatihan adalah suatu proses dimana orang orang mencapai kemampuan tertentu untuk membantu mencapai tujuan organisasi". Oleh karena itu, proses ini terikat dengan berbagai tujuan organisasi, pelatihan dapat dipandang secara sempit maupun luas. Secara terbatas, pelatihan menyediakan para pegawai dengan pengetahuan yang spesifik dan dapat diketahui serta keterampilan yang digunakan dalam pekerjaan mereka saat ini. Pelatihan menurut Dessler (2010:280) adalah "Proses mengajarkan karyawan baru atau yang ada sekarang, keterampilan dasar yang mereka butuhkan untuk menjalankan pekerjaan mereka". Pelatihan merupakan salah satu usaha dalam meningkatkan mutu sumber daya manusia dalam dunia kerja.

Karyawan yang baru ataupun yang sudah bekerja perlu mengikuti pelatihan karena adanya tuntutan pekerjaan yang dapat berubah akibat perubahan lingkungan kerja, strategi, dan lain sebagainya. Menurut Hariandja (2002:169), Alasan diterapkannya pelatihan bagi karyawan adalah pegawai yang baru direkrut sering kali belum memahami secara benar bagaimana melakukan pekerjaan, perubahanperubahan dalam lingkungan kerja dan tenaga kerja, meningkatkan daya saing perusahaan dan memperbaiki produktifitas karyawan, dan karyawan menyesuaikan dengan peraturan-peraturan yang ada. Mangkuprawira (2002:135) menjelaskan bahwa: "Pelatihan adalah sebuah proses mengajarkan pengetahuan dan keahlian tertentu serta sikap agar karyawan semakin terampil dan mampu melaksanakan tanggung jawab dengan semakin baik, sesuai dengan standar". Pelatihan merupakan salah satu aspek penting yang harus dilakukan setiap perusahaan, baik perusahaan BUMN, BUMD, Maupun Perusahaan Swasta. PT. Dahana (Persero) Subang sebagai Salah Satu perusahaan BUMN industri strategis dengan visi menjadi industry nasional yang terunggul dalam bidang bahan berenergi tinggi dengan menghasilkan barang dan jasa yang memiliki daya saing tinggi dan ramah lingkungan, sedangkan misinya adalah menyediakan jasa peledakan komersial terpadu, jasa peledakan untuk bidang pertahanan dan jasa pendukung lainnya. 
Kegiatan usaha PT. Dahana (Persero) Subang mencakup bidang produk bahan peledak dan pengembangan inovasi bahan peledak untuk mendukung kemandirian alutsista nasional. Di kawasan PT. Dahana (Persero) Subang terdapat kantor manajemen pusat, yang biasa disebut KAMPUS PT. Dahana (Persero) berlokasi di dalam kawasan Energetic Material Center (EMC), di Kecamatan Cibogo, Kabupaten Subang, Jawa Barat. Fenomena yang terjadi di PT. Dahana (Persero) Subang disinyalir mengindikasikan karyawan yang bekerja di PT. Dahana (Persero) Subang menunjukkan kinerja yang kurang optimal. Hal tersebut dapat tergambarkan pada tabel 1.1 yaitu pencapaian kinerja perusahaan tahun 2017 - 2018 yang realisasinya masih belum sepenuhnya memenuhi target. Pada Perspektif Pelanggan pencapaiannya masih sama dengan perpektif keuangan. Bisa kita lihat pada KPI di tahun 2017 realisasinya memenuhi target semua, sedangkan pada tahun 2018 ada satu KPI yang realisasinya tidak memenuhi target yakni pada total pendapatan usaha. Pada Perspektif Proses Internal tahun 2017 ada lima KPI yang realisasinya memenuhi target meliputi Laporan Tepat Waktu Penyampaian Lap.Kinerja Intern, jumlah pendaftaran HAKI, Derajat Pemenuhan Pengendalian Resiko Kecelakaan, sertifikat prover, dan perputaran persediaan. Adapun yang tidak memenuhi target pada tahun 2017 yaitu pada alternatif sumber pendanaan. Sedangkan pada tahun 2018 hanya terdapat tiga KPI yang realisasinya mencapai target yaitu pada jumlah pendaftaran HAKI, Derajat Pemenuhan Pengendalian Resiko Kecelakaan, dan sertifikasi profer. Pada Perspektif Organisasi dan Sumber Daya Manusia pada tahun 2017 masih lebih optimal dibandingkan dengan tahun 2018 yang dimana hanya terdapat tiga KPI yang realisasinya tercapai yaitu hanya pada investasi strategis, hasil audit internal GCG, dan efektivitas penyaluran dana. Sedangkan pada KPI yang lainnya tidak memenuhi target. Berbeda dengan tahun 2017, dari keseluruhan KPI ada delapan yang telah memenuhi target dan empat yang tidak memenuhi target yaitu pada rasio produktivitas, optimalisasi implementrasi SAP, efektivitas penyaluran dana, dan employee turn over.

Dilihat dari uraian tersebut, dapat diketahui bahwa pencapaian kinerja perusahaan PT. Dahana (Persero) mengalami penurunan pencapaian dari yang telah ditargetkan oleh perusahaan tahun 2017 - 2018 yang dimana akan menjadi salah satu hambatan perusahaan, hal ini diduga terjadi karena masih belum optimal dan masih rendahnya kinerja setiap karyawan PT. Dahana (Persero), sehingga terlihat pada realisasi pencapaian hasil kinerja perusahaan secara kualitas dan kuantitas yang menurun. Pelatihan dan sarana pelatihan yang diberikan oleh perusahaan maupun pelatihan diluar perusahaan terhadap karyawannya harus menjadi suatu kebutuhan untuk mencapai tujuan organisasi dalam jangka waktu panjang dengan melibatkan partisipasi aktif para karyawannya.Karyawan yang mempunyai dedikasi tinggi terhadap pekerjaan yang diembannya maka secara signifikan tentu akan menghasilkan keluaran berupa kinerja karyawan yang tinggi, namun sebaliknya jika karyawan tersebut kurang optimal dalam melaksanakan tugas yang di embannya, maka kinerja karyawan tersebut dipastikan kurang baik. Pendapat tersebut sesuai dengan hasil penelitian yang dilakukan oleh (Ostrof, 2003; Rivai ,2004). 


\section{Kerangka Teori}

\section{Konsep Manajemen Sumber Daya Manusia}

Pada mulanya orang mendirikan bisnis dalam bentuk kecil, dengan beberapa orang karyawan. Lama kelamaan bisnisnya maju dan membutuhkan banyak karyawan. Bisnis ini harus dipecah-pecah menjadi banyak departemen, harus dipimpin oleh tenaga yang sesuai dengan jabatan dan memiliki banyak karyawan.Para karyawan tersebut bukan saja memiliki kualifikasi tertentu, akan tetapi dia harus mau bekerja. Pekerja yang berkualifikasi baik sekalipun, bisa saja tidak senang dan tidak produktif jika tidak tertarik dengan pekerjaan yang ditugaskan kepadanya. Seorang pekerja yang efektif ialah orang yang tertarik dan senang dengan jabatannya, mau memperbaiki cara kerjanya, mau bekerja sama dengan orang lain atau dengan kelompok. Kemudian ada proses dimana para karyawan bisa menaikan level kemampuannya terhadap perkerjaanya yang sedang dilaksanakan maupun pekerjaannya dimasa yang akan datang. SDM sebagai salah satu unsur penunjang organisasi, dapat diartikan sebagai manusia yang bekerja di lingkungan suatu organisasi (disebut personil, tenaga kerja, pekerja/karyawan), atau postensi manusiawi sebagai penggerak organisasi dalam mewujudkan eksistensinya, potensi yang merupakan aset dan berfungsi sebagai modal non-material dalam organisasi bisnis, yang dapat mewujudkan menjadi potensi nyata secara fisik dan nonfisik dalam mewujudkan eksistensi organisasi. Mengingat betapa pentingnya peran SDM untuk kemajuan organisasi, maka organisasi dengan modal yang lebih moderat menekankan pada fungsi SDM dengan orientasi jangka panjang. Berikut ini adalah pengertian Manajemen Sumber Daya Manusia menurut para ahli.

Menurut Veithzal Rivai (2009:1) "Manajemen Sumber Daya Manusia merupakan salah satu bidang dari manajemen umum yang meliputi segi - segi perencanaan, pengorganisasian, pelaksanaan, dan pengendalian". Menurut Mangkunegara (2015:61) "Manajemen sumber daya manusia adalah suatu perencanaan, pengorganisasian, pengkordinasian, pelaksanaan dan pengawasan terhadap pengadaan, pengembangan, pemberian balas jasa, penginteregasian, pemeliharaan, dan pemisahan tenaga kerja dalam rangka mencapai tujuan organisasi". Hal di atas, menunjukan bahwa manajemen melalui beberapa tahap yaitu tahap perencanaan yang bekaitan dengan perumusan apa yang akan menjadi sasaran, kemudian pengorganisasian yang dilanjutkan dengan pengkoordinasian bertujuan untuk terstrukturnya sistem - sistem dalam manajemen, dan yang terakhir yaitu pelaksanaan dan pengawasan terhadap proses yang menjadi sasaran.Menurut Sadili Samsudin (2006:22) “Mananajemen Sumber Daya Manusia merupakan aktivitasaktivitas yang dilaksanakan agar sumber daya manusia dalam organisasi dapat didaya gunakan secara efektif dan efisien guna mencapai berbagai tujuan". Menurut Malayu SP. Hasibuan, (2008:10) "Manajaemen Sumber Daya Manusia adalah ilmu dan seni mengatur hubungan dan peranan tenaga kerja agar efektif dan efisien membantu terwujudnya tujuan perusahaan, karyawan, dan masyarakat". Berdasarkan definisi para ahli dapat disimpulkan bahwa Manajemen Sumber Daya Manusia adalah ilmu dan seni mendayagunakan manusia atau proses memperoleh, memajukan, mengembangkan, dan memelihara tenaga kerja sampai sedemikian rupa sehingga tujuan organisasi dapat tercapai secara efektif dan efisien. 


\section{Konsep Pelatihan}

Pelatihan adalah suatu proses yang meliputi serangkaian tindakan (upaya) yang dilaksanakan dengan sengaja dalam bentuk pemberian bantuan kepada tenaga kerja yang dilakukan oleh tenaga profesional kepelatihan dalam satuan waktu yang bertujuan untuk meningkatkan kemampuan kerja peserta dalam bidang pekerjaan tertentu guna meningkatkan efektivitas dan produktivitas dalam suatu organisasi. Ada dua tujuan diadakannya program pelatihan. Pertama, pelatihan dilakukan untuk menutupi "gap" antara kecapakan atau kemampuan pegawai dengan permintaan jabatan. Untuk memperoleh gambaran tentang pelatihan yang lebih jelas berikut ini disampaikan definisi dari beberapa ahli: Menurut Dessler dalam Agusta dan Sutanto (2013:1), mendefinisikan pelatihan sebagai berikut: "Pelatihan adalah proses mengajarkan karyawan baru atau yang ada sekarang, keterampilan dasar yang mereka butuhkan untuk menjalankan pekerjaan mereka". Sedangkan menurut Menurut Rae dalam Sofyandi (2008:113), mendefinisikan pelatihan sebagai berikut: "Pelatihan adalah suatu usaha untuk meningkatkan pengetahuan dan kemampuan karyawan dalam melaksanakan pekerjaannya lebih efektif dan efisien. Program pelatihan adalah serangkaian program yang dirancang untuk meningkatkan pengetahuan dan kemampuan karyawan dalam hubungannya dengan pekerjaannya. Efektifitas program pelatihan adalah suatu istilah untuk memastikan apakah program pelatihan dijalankan dengan efektif dalam mencapai sasaran yang ditentukan". Adapun menurut Mangkuprawira (2004:135), mendefinisikan pelatihan sebagai berikut: "Pelatihan merupakan sebuah proses mengajarkan pengetahuan dan keahlian serta sikap agar karyawan semakin terampil dan mampu melaksanakan tanggung jawabnya dengan semakin baik, sesuai dengan standar." Dari definisidefinisi tersebut dapat disimpulkan bahwa pelatihan secara tegas dapat dipisahkan, yaitu usaha meningkatkan keterampilan maupun pengetahuan secara teknis bagi karyawan, dan berupa proses yang membantu para tenaga kerja untuk memperoleh efektivitas dalam pekerjaan mereka yang sekarang atau yang akan datang melalui pengembangan pikiran, tindakan, kecakapan/skill, pengetahuan, dan sikap yang layak.

Suatu organisasi perlu menyelenggerakan kegiatan pelatihan agar pegawai dapat mempelajari perilaku kerja baru tertentu. Serangkaian pelatihan yang dirancang untuk maksud tersebut dapat ditempuh melalui prosedur yang efektif dan efisien. Dalam hal ini Wungu dan Brotoharsojo (2003:135), menyatakan tujuan pelatihan adalah sebagai berikut:

1. Menyiapkan pegawai dalam penguasaan tertentu.

2. Meningkatkan kinerja atau performasi dan produktivitas para pegawai pemegang jabatan-jabatan perusahaan.

3. Memberikan kaesempatan belajarsebagai bagian dari program pengembangan diri dan karir pegawai.

4. Menyiapkan para pegawai agar dapat menangani atau mengerjakan material atau produk baru, metode baru, peralatan dan teknologi baru.

5. Menyiapkan para lulusan dari berbagai tingkatan sekolah atau pendidikan umum agar dapat melampaui masa transisi untuk memasuki situasi kerja yang nyata dari suatu perusahaan atau organisasi. 
6. Memungkinkan diselenggarakannya perencanaan sumber daya manusia yang lebih intregative dan komprehensif dengan kebijakan personalia lainnya sehingga kinerja dan produktivitas kerja pegawai yang tinggi dapat berpengaruh langsung pada peningkatan kinerja perusahaan secara keseluruhan.

Dengan adanya tujuan pelatihan, diharapkan pelatihan dapat menghasilkan suatu perubahan kemampuan maupun wawasan dan perilaku kerja terhadap kinerja karyawan kearah yang lebih baik. Indikator-indikator pelatihan menurut Triton (2005:87), sebagai berikut :

1. Tujuan

Pelatihan merupakan tujuan yang ditetapkan, khususnya terkait dengan penyusunan rencana aksi (action play) dan penetapan sasaran, serta hasil yang diharapkan dari pelatihan yang akan diselenggarakan.

2. Sasaran

Sasaran pelatihan harus ditentukan dengan kriteria yang terinci dan terukur (mesurable).

3. Pelatih

Mengingat pelatihan umumnya berorientasi pada peningkatan skill, maka para pelatih yang dipilih untuk memberikan materi pelatihan harus benar-benar memilih kualifikasi yang memadai sesuai bidangnya, perfessonal, dan kompeten.

4. Materi

Pelatihan sumber daya manusia memerlukan materi atau kurikulum yang sesuai dengan tujuan pelatihan sumber daya manusia yang hendak dicapai oleh organisasi.

5. Metode

Metode pelatihan akan lebih menjamin berlangsungnya kegiatan pelatihan sumber daya manusia yang efektif apabila sesuai dengan jenis materi dan kemampuan peserta pelatihan.

6. Peserta pelatihan

Peserta pelatihan tentunya harus diseleksi berdasarkan persyaratan tertentu dan kualifikasi yang sesuai.

Jika suatu organisasi tidak secara akurat menentukan kebutuhannya, maka program pelatihan secara keseluruhan akan memiliki imbas/pengaruh kecil dalam mencapai apa yang diinginkannya.

\section{Konsep Kinerja}

Keberhasilan suatu organisasi dalam rangka mencapai tujuannya tergantung dari kemampuan dan kehandalan sumber daya manusia yang mengoperasikan unitunit kerja yang terdapat didalam organisasi yang bersangkutan. Untuk itu diperlukan kinerja yang tinggi dari pelaku-pelaku kegiatan tersebut. Berikut ini adalah beberapa pengertian dari kinerja menurut para ahli, yaitu :Menurut Mangkunegara (2004:67), mendefinisikan kinerja sebagai berikut: "Hasil kerja secara kualitas dan kuantitas yang telah dicapai oleh seseorang karyawan dalam melaksanakan tugasnya sesuai dengan tanggung jawab yang diberikan kepadanya".Sedangkan menurut Malayu Hasibuan (2002:160), mendefinisikan kinerja sebagai berikut : "Kinerja adalah suatu 
hasil kerja yang dicapai seseorang dalam melaksanakan tugas-tugas yang didasarkan atas kecakapan, usaha, kesempatan, pengalaman dan kesungguhan serta waktu menurut standar dan kriteria yang telah ditetapkan sebelumnya". Adapun menurut Veizal Rivai (2004:309) "Kinerja adalah perilaku yang nyata yang ditampilkan setiap orang sebagai prestasi kerja yang dihasilkan oleh karyawan sesuai dengan perannya dalam perusahaan" Dan menurut Wibowo (2007:7), mendefinisikan kinerja sebagai berikut: "Kinerja mempunyai makna yang lebih luas, bukan hanya hasil kerja, tetapi termasuk bagaimana proses pekerjaan berlangsung". Dari beberapa pengertian tentang kinerja tersebut di atas dapat disimpulkan bahwa kinerja adalah sesuatu ataupun prestasi kerja yang telah dicapai oleh seseorang. Kinerja merupakan hasil akhir dari suatu aktifitas yang telah dilakukan seseorang untuk meraih suatu tujuan. Pencapaian hasil kerja ini juga sebagai bentuk perbandingan hasil kerja seseorang dengan standar yang telah ditetapkan. Apabila hasil kerja yang dilakukan oleh seseorang sesuai dengan standar kerja atau bahkan melebihi standar maka dapat dikatakan kinerja itu mencapai optimalisasi yang baik.

Menurut Kasmir (2016:65-71), faktor-faktor yang mempengaruhi kinerja yaitu :

1. Kemampuan dan Keahlian

Merupakan kemampuan atau skill yang dimiliki seseorang dalam melakukan suatu pekerjaan. Semakin memiliki kemampuan dan keahlian maka akan dapat menyelesaikakn pekerjaannya secara benar, sesuai dengan yang telah ditetapkan. Artinya karyawan yang memiliki kemampuan dan keahlian yang lebih baik, maka akan memberikan kinerja yang baik pula demikian sebaliknya. Dengan demikian kemampuan dan keahlian akan mempengaruhi kinerja seseorang.

2. Pengetahuan

Maksudnya adalah pengetahuan tentang pekerjaan. Seseorang yang memiliki pengetahuan tentang pekerjaan secara baik akan memberikan hasil pekerjaan yang baik, demikian sebaliknya. Jadi dapat disimpulkan bahwa pengetahuan tentang pekerjaan akan mempengaruhi kinerja.

3. Rancangan Kerja

Merupakan rancangan pekerjaan yang akan memudahkan dalam mencapai tujuannya. Artinya jika suatu pekerjaan memiliki rancangan yang baik, maka akan memudahkan untuk menjalankan pekerjaan tersebut secara teapt dan benar. Demikian pula sebaliknya, maka dapat disimpulkan bahwa rancangan pekerjaan akan mempengaruhi kinerja seseorang.

4. Kepribadian

Yaitu kepribadian seseorang atau karakter yang dimiliki seseorang. Setiap orang memiliki kepribadian atau karakter yang berbeda satu dengan yang lainnya. Seseorang yang memiliki kepribadian atau karakter yang baik akan dapat melakukan pekerjaan secara sungguh-sungguh penuh tanggung jawab sehingga hasil pekerjaan juga baik.

5. Motivasi Kerja

Motivasi kerja merupakan dorongan bagi seseorang untuk melakukan pekerjaan. Jika karyawan memiliki dorongan yang kuat dari dalam dirinya atau dorongan dari luar dirinya (misalnya dari pihak perusahaan), maka karyawan akan terangsang atau terdorong untuk melakukan pekerjaan dengan bai. Pada 
akhirnya dorongan atau rangsangan baik dari dalam maupun dari luar diri seseorang akan mengahasilkan kinerja yang baik.

6. Kepemimpinan

Kepemimpinan merupakan perilaku seorang pemimpin dalam mengatur, mengelola dan memerintah bawahannya untuk mengerjakan suatu tugas dan tanggung jawab yang diberikannya.

7. Gaya Kepemimpinan

Merupakan gaya atau sikap seorang pemimpin dalam menghadapi atau memerintah bawahannya.

8. Budaya Organisasi

Merupakan kebiasaan-kebiasaan atau norma-norma yan berlaku dan dimiliki oleh suatu organisasi atau perusahaan. Kebiasaan-kebiasaan atau norma-norma ini mengatur hal-hal yang berlaku dan diterima secara umum serta harus dipatuhi oleh segenap anggota suatu perusahaan atau organisasi.

9. Kepuasan Kerja

Merupakan perasaan senang atau gembira, atau perasaan suka seseorang sebelum dan setelah melakukan suatu pekerjaan. Jika karyawan merasa senang atau gembira atau suka untuk bekerja, maka hasil pekerjaan akan baik pula

10. Lingkungan Kerja

Merupakan suasana atau kondisi disekitar lokasi tempat bekerja. Lingkungan kerja dapat berupa rungan, layout, sarana dan prasarana serta hubungan kerja dengan sesama rekan kerja.

11. Loyalitas

Merupakan kesetiaan karyawan untuk tetap bekerja dan membela perusahaan di mana tempatnya bejerha. Kesetiaan ini ditunjukan dengan terus bekerja sungguh-sungguh sekalipun perusahaannya dalam kondisi kurang baik.

12. Komitmen

Merupakan kepatuhan karyawan untuk menjalankan kebijakan atau peraturan perusahaan dalam bekerja. Komitmen juga dapat diartikan kepatuhan karyawan kepada janji-janji yang telah dibuatnya. Atau dengan kata lain komitmen merupakan kepatuhan untuk menjalankan keputusan yang telah dibuat.

13. Disiplin Kerja

Merupakan usaha karyawan untuk menjalankan aktivitas kerjanya secara sungguh-sungguh. Disiplin kerja dalam hal ini dapat berupa waktu, misalnya masuk kerja selalu tepat waktu. Kemudian disiplin dalam mengerjakan apa yang diperintahkan kepadanya sesuai dengan perintah yang harus dikerjakan. Karyawan yang disiplin akan mempengaruhi kinerja.

Menurut Hasibuan (2008:89), tujuan dan kegunaan penilaian kinerja karyawan yaitu:

1. Sebagai dasar dalam pengambilan keputusan yang digunakan untuk promosi, demosi, pemberhentian, dan penetapan besarnya balas jasa.

2. Untuk mengukur prestasi kerja yaitu sejauh mana karyawanbisa sukses dalam pekerjaannya.

3. Sebagai dasar untuk mengevaluasi efektivitas seluruh kegiatan didalam perusahaan. 
4. Sebagai dasar untuk mengevaluasi program latihan dan keefektifan jadwal kerja, metode kerja, struktur organisasi, gaya pegawasan, kondisi kerja, dan peralatan kerja.

5. Sebagai indikator untuk menentukan kebutuhan akan latihan bagi karyawan yang berada didalam organisasi.

6. Sebagai alat untuk mendapatkan performance kerja yang baik.

7. Sebagai alat pendorong atau untuk membiasakan para atasan untuk mengobservasikan perilaku bawahan supaya diketahui minat dan kebutuhan kebutuhan bawahannya.

8. Sebagai alat untuk bisa melihat kekurangan atau kelemahan- kelemahan di masa lampau dan meningkatkan kemampuan karyawan selanjutnya.

9. Sebagai kriteria didalam menentukan seleksi dan penempatan karyawan.

10. Sebagai alat untuk mengidentifikasi kelemahan-kelemahan karyawan dan dengan demikian bisa sebagai bahan pertimbangan karyawan.

11. Sebagai alat untuk memperbaiki atau mengembangkan kecakapan karyawan.

12. Sebagai dasar untuk memperbaiki dan mengembangkan uraian pekerjaan.

Program ini dilaksanakan untuk mengevaluasi kinerja yang ada sehingga dapat segera mengambil tindakan bila terdapat hal yang menyimpang dari penilaian kinerja tersebut. Selain itu penilaian kinerja karyawan juga mendorong para karyawan untuk meningkatkan kuantitas dan kualitas kerjanya demi perusahaan.

Menurut Robbins (2006:206), mengungkapkan beberapa dimensi atau kriteria yang perlu mendapat perhatian sebagai indikator dalam pengukuran kinerja, antara lain :

1. Kuantitas

Jumlah kerja yang dilakukan dalam satu periode yang telah ditentukan.

2. Kualitas

kualitas kerja yang diukur dari persepsi karyawan terhadap kualitas pekerjaan yang dihasilkan serta kesempurnaan tugas terhadap keterampilan dan kemampuan karyawan.

3. Ketepatan Waktu

Ketepatan waktu merupakan tingkat aktivitas diselesaikan pada awal waktu yang dinyatakan, dilihat dari sudut koordinasi dengan hasil output serta memaksimalkan waktu yang tersedia untuk aktivitas lain.

4. Efektivitas

Efektivitas merupakan tingkat penggunaan sumber daya organisasi (tenaga, uang teknologi, bahan baku) dimaksimalkan dengan maksud menaikkan hasil setiap unit dalam penggunaan sumber daya.

5. Kemandirian

Merupakan tingkat seorang karyawan yang nantinya akan dapat menjalankan fungsi kerjanya.

6. Komitmen Kerja

Komitmen kerja merupakan suatu tingkat dimana karyawan memiliki komitmen kerja dengan instansi dan tanggung jawab karyawan terhadap kantor. 


\section{Hasil dan Pembahasan}

\section{Profil PT . Dahana (Persero) Subang}

PT. DAHANA (Persero) atau "DAHANA" adalah Badan Usaha Milik Negara (BUMN) di bidang industri strategis yang menyediakan layanan bahan peledak terpadu untuk sektor Migas, Pertambangan Umum, Kuari dan Konstruksi serta untuk Pertahanan. Sejarah DAHANA sebagai pionir di industri ini berawal dari proyek Angkatan Udara Republik Indonesia (AURI) pada tahun 1966 yang dikenal dengan Proyek Menang, berlokasi di Tasikmalaya, Jawa Barat. Kemudian, pada tahun 1973 secara resmi menjadi Perusahaan Umum DAHANA berdasarkan Peraturan Pemerintah No. 36/1973 sebelum ditetapkan sebagai Perusahaan Perseroan pada tahun 1991. Lini Bisnis DAHANA terus berkembang mencakup: Explosives Manufacturing, Drilling \& Blasting, Related Services, dan Defence Related untuk pelanggan di seluruh Indonesia dan dunia. Barang dan jasa DAHANA digunakan setiap hari oleh berbagai industri di Indonesia, dari sektor pertambangan umum, baik logam, mineral maupun batubara; sektor kuari dan konstruksi seperti industri semen, aspal dan penggalian batu andesit; proyek konstruksi seperti dam, terowongan, irigasi, penghancuran gedung-gedung tua, pendalaman pelabuhan; sektor minyak dan gas seperti operasi perforasi casing sumur minyak, operasi seismik; dan juga operasi militer. Sebagai pionir di industri peledakan dengan reputasi terpercaya sebagai produsen bahan peledak dan penyedia jasa peledakan menyeluruh, DAHANA memenuhi seluruh kebutuhan tahapan proses peledakan. Barang dan jasa DAHANA digunakan oleh berbagai industri di Indonesia, mulai dari sektor pertambangan umum, kuari dan konstruksi, minyak dan gas serta pertahanan. Dalam era lahir kembali, DAHANA saat ini ingin melayani negeri lebih baik dari sebelumnya dan menjadi mitra pemerintah dalam pengembangan industri pertahanan di tanah air. SERVING THE NATION BETTER! Sebagai motto perusahaan.

\section{Analisis Deskriptif Variabel Pelatihan}

Terdapat enam indikator yang menjadi tolak ukur variabel pelatihan, yaitu tujuan, sasaran, pelatih, materi, dan peserta. Dari keenam dimensi tersebut dapat dijelaskan sebagai berikut berdasarkan hasil penelitian penulis pada saat dilapangan kemudian dikakukan analisis deskriptifnya. Tujuan pelatihan dan hasil jawaban responden, terdapat tiga pernyataan yang berhubungan dengan indikator Tujuan Pelatihan, terdapat 66 responden yang menjawab dan dapat dilihat dalam bentuk tabel sebagai berikut:

Tabel 1

Jawaban atas Pernyataan Indikator Tujuan Pelatihan

$$
(\mathrm{N}=66)
$$

\begin{tabular}{|c|c|c|c|c|c|c|c|c|c|c|}
\hline \multirow{4}{*}{$\begin{array}{c}\mathrm{N} \\
\mathrm{O}\end{array}$} & \multirow{4}{*}{$\begin{array}{c}\text { Indikat } \\
\text { or }\end{array}$} & \multirow{2}{*}{\multicolumn{5}{|c|}{ Jawaban }} & \multirow{4}{*}{$\sum$} & \multirow{4}{*}{$\begin{array}{c}\text { Tota } \\
1 \\
\text { Skor }\end{array}$} & \multirow{4}{*}{$\begin{array}{c}\text { Sko } \\
\text { r } \\
\text { Idea } \\
1\end{array}$} & \multirow{4}{*}{$\begin{array}{c}\text { Presentas } \\
\text { e }\end{array}$} \\
\hline & & & & & & & & & & \\
\hline & & 1 & 2 & 3 & 4 & 5 & & & & \\
\hline & & $\begin{array}{c}\text { ST } \\
\text { S }\end{array}$ & $\begin{array}{l}\mathrm{T} \\
\mathrm{S}\end{array}$ & $\mathrm{R}$ & $S$ & SS & & & & \\
\hline 1 & X1.1 & 3 & 28 & 0 & 35 & 0 & 66 & 199 & \multirow{3}{*}{330} & $60,30 \%$ \\
\hline 2 & $\mathrm{X} 1.2$ & 7 & 26 & 0 & 33 & 0 & 66 & 191 & & $57,87 \%$ \\
\hline 3 & $\mathrm{X} 1.3$ & 5 & 18 & 27 & 16 & 0 & 66 & 186 & & $56,36 \%$ \\
\hline
\end{tabular}

Sumber: Data yang Diolah, 
a. Tanggapan responden mengenai pernyataan pelatihan dapat meningkatkan keterampilan dan partisipasi karyawan dalam volume pekerjaan untuk mengejar target perusahaan. (X1.2).

Berdasarkan tabel diatas, hasil jawaban responden untuk pernyataan tersebut adalah menjawab sangat tidak setuju 3 responden $(4,5 \%)$, tidak setuju responden 28 responden $(42,4 \%)$, ragu-ragu 0 responden $(0 \%)$, setuju 35 responden $(53 \%)$, sangat setuju 0 responden $(0, \%)$. Dari hasil jawaban diatas, setuju merupakan jawaban terbanyak mengenai pernyataan pelatihan dapat meningkatkan keterampilan dan partisipasi karyawan dalam volume pekerjaan untuk mengejar target perusahaan.Jika dihubungkan dengan praktiknya di lapangan, pelatihan membuat para karyawan PT. Dahana (Persero) dapat meningkatkan keterampilan dan minat partisipasi karyawan dalam menekan volume pekerjaan sehingga mereka dapat mengejar target yang diberikan oleh perusahaan. Untuk 3 responden menjawab sangat tidak setuju dapat disimpulkan bahwa tidak semua pelatihan dapat meningkatkan keterampilan, minat, dan volume pekerjaan. Hal itu karena masih ada program pelatihan yang masih mengabaikan kebutuhan akan penentuan apakah tujuan pelatihan tercapai.

b. Tanggapan responden mengenai pernyataan pelatihan meningkatkan wawasan dan pemahaman karyawan pada pekerjaan yang ditanganinya dan atau pada pekerjaan yang baru (X1.2).

Berdasarkan tabel diatas, hasil jawaban responden untuk pernyataan tersebut adalah menjawab sangat tidak setuju 7 responden $(10,6 \%)$, tidak setuju 26 responden $39,4 \%$ ), ragu-ragu 0 responden $0 \%$, setuju 33 responden (50\%), sangat setuju 0 responden $(0 \%)$. Dari hasil jawaban diatas, sangat setuju merupakan jawaban terbanyak mengenai pernyataan pelatihan meningkatkan wawasan dan pemahaman karyawan pada pekerjaan yang ditanganinya dan atau pada pekerjaan yang baru. Pada implementasinya, pelatihan bagi karyawan PT. Dahana (Persero) merupakan suatu proes untuk peningkatan pengetahuan dan pemahaman mengenai job description para karyawan yang sedang ditanganinya atau pekerjaan yang suatu saat akan ditanganinya. Untuk 7 responden menjawab sangat tidak setuju dapat di katakan bahwa tidak jarang pelatihan yang diberikan memberikan pemahaman dan wawasan yang diberikan untuk pekerjaan baru yang akan ditangani karyawan, hal ini karena masih belum sering diberikan, dan pelatihan lebih sering memfokuskan pada pekerjaan karyawan yang sedang ditangani. Menurut Fandy dan Anastasia (1995:223) adalah untuk meningkatkan pengetahuan, keterampilan, dan sikap karyawan serta meningkatkan kualitas dan produktivitas organisasi secara keseluruhan.

c. Tanggapan responden mengenai pernyataan pelatihan meningkatkan kemampuan untuk melihat masalah dari berbagai arah (X1.3).

Berdasarkan tabel diatas, hasil jawaban responden untuk pernyataan tersebut adalah menjawab sangat tidak setuju 5 responden $(7,6 \%)$, tidak setuju 18 responden $(27,5 \%)$, ragu-ragu 27 responden $(40,9 \%)$, setuju 16 responden $(24,2 \%)$, sangat setuju 0 responden $(0 \%)$. Dari hasil jawaban diatas, setuju merupakan jawaban terbanyak mengenai pernyataan Pelatihan meningkatkan kemampuan untuk melihat masalah dari berbagai arah. Jika dikaitkan dengan praktiknya, pelatihan pada PT. Dahana (Persero) merupakan salah satu cara meningkatkan kemampuan 
karyawan dalam memecahkan masalah-masalah perusahaan dan menuntaskan pekerjaan mereka secara efektif. Untuk 5 responden menjawab sangat tidak setuju dapat dijelaskan bahwa ternyata setelah saya amati lebih jauh lagi di perusahaan ini, bahwa persoalan-persoalan organisasional yang menghantam dari berbagai arah dan ada dilema yang tidak mudah untuk dipecahkan dan dihadapi.

\section{Sasaran}

Hasil jawaban responden, terdapat dua pernyataan yang berhubungan dengan indikator Sasaran, terdapat 66 responden yang menjawab dan dapat dilihat dalam bentuk tabel sebagai berikut:

Tabel 2

Jawaban atas Pernyataan Indikator Sasaran

$(\mathrm{N}=66)$

\begin{tabular}{|c|c|c|c|c|c|c|c|c|c|c|}
\hline \multirow{3}{*}{ No } & \multirow{3}{*}{ Indikat } & \multicolumn{5}{|c|}{ Jawaban } & \multirow{3}{*}{$\sum$} & \multirow{3}{*}{$\begin{array}{c}\text { Tota } \\
1 \\
\text { Skor }\end{array}$} & \multirow{3}{*}{$\begin{array}{c}\text { Skor } \\
\text { Idea } \\
1\end{array}$} & \multirow[t]{3}{*}{ Presentase } \\
\hline & & 1 & 2 & 3 & 4 & 5 & & & & \\
\hline & & $\begin{array}{c}\text { ST } \\
\text { S }\end{array}$ & $\begin{array}{l}\mathrm{T} \\
\mathrm{S}\end{array}$ & $\mathrm{R}$ & $S$ & SS & & & & \\
\hline 1 & X1.4 & 4 & 16 & 31 & 15 & & 66 & 189 & \multirow{2}{*}{330} & $57,27 \%$ \\
\hline 2 & X1.5 & 4 & 18 & 29 & 15 & & 66 & 187 & & $56,66 \%$ \\
\hline
\end{tabular}

Sumber: Data yang Diolah, 2018

a. Tanggapan responden mengenai program pelatihan yang diberikan sesuai dengan kebutuhan pekerjaan karyawan (X1.4).

Berdasarkan table diatas, hasil jawaban responden untuk pernyataan tersebut adalah menjawab sangat tidak setuju 4 responden $(6,1 \%)$, tidak setuju 16 responden $(24,2 \%)$, ragu-ragu 31 responden $(47,0 \%)$, setuju 15 responden $(22,7 \%)$, sangat setuju $0(0 \%)$. Dari hasil jawaban diatas, ragu-ragu merupakan jawaban terbanyak mengenai pernyataan program pelatihan yang diberikan sesuai dengan kebutuhan pekerjaan karyawan.

Jika dikaitkan pada PT. Dahana (Persero), program pelatihan tersebut sesuai dengan apa yang di butuhkan mengenai pekerjaan karyawan, sehingga para karyawan merasa bahwa sasaran program pelatihan yang diberikan perusahaan benar dan bermanfaat untuk pekerjaan mereka.

Untuk 4 responden yang menjawab sangat tidak setuju dapat disimpulkan bahwa karyawan tersebut merasa apa yang diterima saat pelatihan bukan untuk pekerjaannya saat ini, melainkan untuk pekerjaannya saat nanti jika karyawan tersebut mendapatkan promosi jabatan.

b. Tanggapan responden mengenai pelatihan yang diberikan sesuai dengan kriteria yang terinci dan terukur sesuai dengan kualifikasi peserta. (X1.5).

Berdasarkan tabel 4.8, hasil jawaban responden untuk pernyataan tersebut adalah menjawab sangat tidak setuju 4 responden $(6,1 \%)$, tidak setuju 18 responden $(27,3 \%)$, ragu-ragu 29 responden $(43,9 \%)$, setuju 15 responden $(22,7,9 \%)$, sangat setuju 0 responden $(0 \%)$. Dari hasil jawaban diatas, ragu-ragu merupakan jawaban terbanyak mengenai pernyataan pelatihan yang diberikan sesuai dengan kriteria yang terinci dan terukur sesuai dengan kualifikasi peserta.

Dalam pelatihan di PT. Dahana (Persero), kriteria yang terinci dan terukur dengan sesuai kualifikasi peserta sebagian sudah sesuai dengan sasaran pelatihan. 
Untuk 18 responden menjawab tidak setuju dan 29 responden menjawab ragu-ragu dapat disimpulkan bahwa masih ada sedikitnya pelatihan yang belum sesuai dengan kriteria yang terukur sesuai dengan kualifikasi peserta. Contohnya pada saat pelatihan juru ledak PT. Dahana (Persero), karyawan di bagian/unit Pelayanan Korporasi di ikut sertakan. Itu sudah termasuk tidak sesuia dengan kualifikasi peserta.

Menurut Veithzal dan Sagala 2013:214) hasil program pelatihan yang ingin dicapai hendaknya dirumuskan dengan jelas agar langkah-langkah persiapan dan pelaksanaan pelatihan dapat diarahkan untuk mencapai sasaran yang di tentukan.

Tabel 3

Jawaban atas Pernyataan Indikator Pelatih

\begin{tabular}{|c|c|c|c|c|c|c|c|c|c|c|}
\hline & \multicolumn{10}{|c|}{$(\mathrm{N}=66)$} \\
\hline \multirow{3}{*}{$\begin{array}{c}\mathrm{N} \\
\mathrm{O}\end{array}$} & \multirow{3}{*}{ Indikat } & \multicolumn{5}{|c|}{ Jawaban } & \multirow{3}{*}{$\sum$} & \multirow{3}{*}{$\begin{array}{l}\text { Total } \\
\text { Skor }\end{array}$} & \multirow{3}{*}{$\begin{array}{c}\text { Skor } \\
\text { Idea } \\
1\end{array}$} & \multirow{3}{*}{$\begin{array}{c}\text { Presentas } \\
\text { e }\end{array}$} \\
\hline & & 1 & 2 & 3 & 4 & 5 & & & & \\
\hline & & $\begin{array}{c}\text { ST } \\
\text { S }\end{array}$ & $\begin{array}{l}\mathrm{T} \\
\mathrm{S}\end{array}$ & $\mathrm{R}$ & $S$ & SS & & & & \\
\hline 1 & X1.6 & 2 & 7 & 29 & 15 & 0 & 66 & 205 & \multirow{2}{*}{330} & $62,12 \%$ \\
\hline 2 & X1.7 & 3 & 8 & 29 & 26 & 0 & 66 & 210 & & $63,63 \%$ \\
\hline
\end{tabular}

Sumber: Data yang Diolah, 2019

c. Tanggapan responden mengenai program pelatihan yang diberikan sesuai dengan kebutuhan pekerjaan karyawan (X1.6).

Berdasarkan tabel diatas, hasil jawaban responden untuk pernyataan tersebut adalah menjawab sangat tidak setuju 2 responden $(3,0 \%)$, tidak setuju 7 responden $(10,6 \%)$, ragu-ragu 39 responden $(59,1 \%)$, setuju 18 responden $(27,3 \%)$, sangat setuju 0 responden $(0 \%)$. Pada PT. Dahana (Persero), pelatih/instruktur telah cukup memberikan materi yang sesuai dengan kurikulum pelatihan. Untuk 39 responden yang menjawab ragu-ragu dan 7 responden menjawab tidak setuju dapat disimpulkan bahwa pelatih kurang memberikan kesempatan untuk bertanya pada si peserta.

d. Tanggapan responden mengenai instruktur pelatihan seseorang yang sudah kompeten dan profesional. (X1.7).

Berdasarkan tabel diatas, hasil jawaban responden untuk pernyataan tersebut adalah menjawab sangat tidak setuju 3 responden $(4,5 \%)$, tidak setuju 8 responden $(12,1 \%)$, ragu-ragu 29 responden $(43,9 \%)$, setuju 26 responden $(49,4 \%)$, sangat setuju 0 responden $(0 \%)$. Dari hasil jawaban diatas, setuju merupakan jawaban terbanyak mengenai pernyataan instruktur pelatihan seseorang yang sudah kompeten dan profesional.Dalam pelatihan di PT. Dahana (Persero), narasumber pada program pelatihan sudah kompeten pada bidangnya. Untuk 8 responden menjawab tidak setuju dan 29 responden menjawab ragu-ragu 8 dapat disimpulkan bahwa instruktur/pelatih lebih sering komunikasi satu arah dibanding komunikasi dua arah, itu menimbulkan tidak leluasanya peserta saat ada yang kurang dimengerti. PT. Dahana (Persero) berusaha memberikan yang terbaik untuk setiap peserta dan diberikan pelatih yang baik. Mangkunegara (2005:72) Para pelatih (trainer) harus ahlinya yang berkualitas memadai (profesional). 


\section{Materi}

Hasil jawaban responden, terdapat tiga pernyataan yang berhubungan dengan indikator materi, terdapat 66 responden yang menjawab dan dapat dilihat dalam bentuk tabel sebagai berikut:

Tabel 4

Jawaban atas Pernyataan Indikator Materi

$(\mathrm{N}=66)$

\begin{tabular}{|c|c|c|c|c|c|c|c|c|c|c|}
\hline \multirow{3}{*}{$\begin{array}{l}\mathrm{N} \\
\mathrm{O}\end{array}$} & \multirow{3}{*}{$\begin{array}{c}\text { Indikat } \\
\text { or }\end{array}$} & \multicolumn{5}{|c|}{ Jawaban } & \multirow{3}{*}{$\sum$} & \multirow{3}{*}{$\begin{array}{c}\text { Tota } \\
1 \\
\text { Skor }\end{array}$} & \multirow{3}{*}{$\begin{array}{l}\text { Skor } \\
\text { Ideal }\end{array}$} & \multirow{3}{*}{$\begin{array}{c}\text { Persentas } \\
\text { e }\end{array}$} \\
\hline & & 1 & 2 & 3 & 4 & 5 & & & & \\
\hline & & $\begin{array}{c}\text { ST } \\
\text { S }\end{array}$ & $\begin{array}{l}\mathrm{T} \\
\mathrm{S}\end{array}$ & $\mathrm{R}$ & $S$ & SS & & & & \\
\hline 1 & X1.8 & 4 & 8 & 34 & 20 & 0 & 66 & 202 & \multirow{3}{*}{330} & $61,21 \%$ \\
\hline 2 & X1.9 & 3 & 9 & 29 & 25 & 0 & 66 & 208 & & $63,03 \%$ \\
\hline 3 & X.110 & 3 & 16 & 34 & 13 & 0 & 66 & 202 & & $61,21 \%$ \\
\hline
\end{tabular}

Sumber: Data yang telah Diolah, 2018

a. Tanggapan responden mengenai materi pelatihan yang diberikan sesuai dengan tujuan pelatihan (X1.8).

Berdasarkan tabel diatas, hasil jawaban responden untuk pernyataan tersebut adalah menjawab sangat tidak setuju 4 responden $(6,1 \%)$, tidak setuju 8 responden (12,1\%), ragu-ragu 34 responden (51,5\%), setuju 20 responden $(30,3 \%)$, sangat setuju 0 responden $(0 \%)$. Jika dilihat pada implementasinya sesuai penuturan karyawan pada PT. Dahana (Persero), materi pelatihan yang diberikan sudah sesuai dengan apa yang menjadi tujuan pelatihan tersebut. Untuk 34 responden yang menjawab ragu-ragu dan 8 responden menjawab tidak setuju dapat disimpulkan bahwa ada materi yang masih rancu yang kesesuaiannya belum jelas diperuntukan untuk bagian unit mana.

b. Tanggapan responden mengenai materi pelatihan yang diberikan sesuai dengan komponen pelatihan (X1.9).

Berdasarkan tabel diatas, hasil jawaban responden untuk pernyataan tersebut adalah menjawab sangat tidak setuju 3 responden $(4,5 \%)$, tidak setuju 9 responden $(13,6 \%)$, ragu-ragu 29 responden $(43,9 \%)$, setuju 25 responden $(37,9 \%)$, sangat setuju 0 responden $(0 \%)$. Jika dikaitkan pada PT. Dahana (Persero), pembahasan materi dari narasumber sudah selaras dengan komponen pelatihan. Untuk 29 responden yang menjawab ragu-ragu dan 9 responden menjawab tidak setuju dapat disimpulkan bahwa sebagian karyawan tersebut merasa materi yang diberikan belum sepenuhnya sesuai dengan komponen pelatihan tersebut, walau hanya pada beberapa waktu pelatihan saja.

c. Tanggapan responden mengenai materi pelatihan sesuai dengan kurikulum (X1.10).

Berdasarkan tabel diatas, hasil jawaban responden untuk pernyataan tersebut adalah menjawab sangat tidak setuju 3 responden (4,5\%), tidak setuju 16 responden $(24,2 \%)$, ragu-ragu 34 responden $(51,5 \%)$, setuju 0 responden $(0 \%)$, sangat setuju 13 responden $(19,7 \%)$. Dengan hal ini materi dalam pelatihan yang dijalankan pada PT. Dahana (Persero) sudah baik sesuai dengan tujuan kurikulum pelatihan.

Untuk 34 responden yang menjawab ragu-ragu dan 16 responden menjawab tidak setuju dapat disimpulkan bahwa ketidaksesuaian materi masih banyak pada 
pelatihan yang di adakan oleh PT. Dahana (Persero) dalam menjalankan kegiatannya, Materi dalam pelatihan menjadi hal utama yang sangat diperhatikan pada saat diadakannya pelatihan atau pendidikan yang dimana itu sangat menunjang untuk menghasilkan peserta yang berkualitas dan berkopeten. Diperkuat oleh Mangkunegara (2005:71) Materi pelatihan dan pengembangan harus disesuaikan dengan tujuan yang hendak di capai.

\section{Metode Pelatihan}

Hasil jawaban responden, terdapat dua pernyataan yang berhubungan dengan indikator metode pelatihan, terdapat 66 responden yang menjawab dan dapat dilihat dalam bentuk tabel sebagai berikut:

Tabel 5

Jawaban atas Pernyataan Indikator Metode

\begin{tabular}{|c|c|c|c|c|c|c|c|c|c|c|}
\hline \multicolumn{11}{|c|}{$(\mathrm{N}=66)$} \\
\hline \multirow{3}{*}{$\begin{array}{l}\mathrm{N} \\
\mathrm{o}\end{array}$} & \multirow{3}{*}{$\begin{array}{c}\text { Indikat } \\
\text { or }\end{array}$} & \multicolumn{5}{|c|}{ Jawaban } & \multirow{3}{*}{$\sum$} & \multirow{3}{*}{$\begin{array}{c}\text { Tota } \\
1 \\
\text { Skor }\end{array}$} & \multirow{3}{*}{$\begin{array}{c}\text { Skor } \\
\text { Idea } \\
1\end{array}$} & \multirow{3}{*}{$\begin{array}{c}\text { Persentas } \\
\text { e }\end{array}$} \\
\hline & & 1 & 2 & 3 & 4 & 5 & & & & \\
\hline & & $\begin{array}{c}\text { ST } \\
\text { S }\end{array}$ & $\begin{array}{l}\mathrm{T} \\
\mathrm{S}\end{array}$ & $\mathrm{R}$ & $S$ & SS & & & & \\
\hline 1 & X1.11 & 2 & 6 & 43 & & 15 & 66 & 218 & 330 & $66,06 \%$ \\
\hline 2 & X1.12 & 3 & 8 & 47 & & 8 & 66 & 200 & 300 & $60,60 \%$ \\
\hline
\end{tabular}

Sumber: Data yang telah Diolah, 2019

d. Tanggapan responden mengenai metode yang digunakan dalam pelatihan sesuai dengan materi pelatihan. (X1.11).

Berdasarkan tabel diatas, hasil jawaban responden untuk pernyataan tersebut adalah menjawab sangat tidak setuju 2 responden $(3,0 \%)$, tidak setuju 6 responden $(9,1 \%)$, ragu-ragu 43 responden $(65,2 \%)$, setuju 0 responden $(0 \%)$, sangat setuju 15 responden $(22,7 \%)$. Dari hasil jawaban diatas, setuju merupakan jawaban terbanyak mengenai pernyataan metode yang digunakan dalam pelatihan sesuai dengan materi pelatihan.Pada praktiknya di lapangan, dalam hal ini penyampaian metode yang diberikan oleh narasumber secara sistematika dalam pelatihan disesuaikan dengan materi pelatihan sudah cukup sesuai.

Untuk 6 responden yang menjawab ragu-ragu dan 2 responden menjawab tidak setuju dapat disimpulkan bahwa metode yang tidak sesuai materi akan menghambat output pelatihan tersebut. Dan ternyata, masih sering terjadi di PT. Dahana (Persero).

e. Tanggapan responde mengenai metode yang diberikan dalam pelatihan sesuai dengan kemampuan karyawan. (X1.12).

Berdasarkan tabel diatas, hasil jawaban responden untuk pernyataan tersebut adalah menjawab sangat tidak setuju 3 responden $(4,5 \%)$, tidak setuju 8 responden $(12,1 \%)$, ragu-ragu 47 responden $(71,2 \%)$, setuju 0 responden $(0 \%)$, sangat setuju 8 responden $(12,1 \%)$. Untuk implementasinya di PT. Dahana (Persero) melalui wawancara peneliti dengan karyawan menjelaskan bahwa metode yang diterima karyawan sudah sesuai dengan kemampuan mereka walaupun tidak sepenuhnya sesuai. Untuk 47 responden yang menjawab ragu-ragu dan 8 responden menjawab 
tidak setuju dapat disimpulkan metode pelatihan di PT. Dahana (Persero) masih perlu diperhatikan.

Metode dalam pelatihan harus sesuai dengan tujuan diadakannya pelatihan pekerja karna itu sangat penting untuk menciptakan para peserta didik yang berkompeten. Djamarah \& Aswan (2006:95) mengemukakan bahwa metode latihan (drill) merupakan suatu cara mengajar yang dapat menanamkan kebiasaan kebiasaan tertentu. Metode ini juga dapat digunakan untuk memperoleh suatu ketangkasan, ketepatan, kesempatan, dan keterampilan

\section{Peserta Pelatihan}

Hasil jawaban responden, terdapat dua pernyataan yang berhubungan dengan indikator peserta pelatihan, terdapat 66 responden yang menjawab dan dapat dilihat dalam bentuk tabel sebagai berikut:

Tabel 6

Jawaban atas Pernyataan Indikator Materi

$(\mathrm{N}=66)$

\begin{tabular}{|c|c|c|c|c|c|c|c|c|c|c|}
\hline \multirow{3}{*}{$\begin{array}{l}\mathrm{N} \\
\mathrm{O}\end{array}$} & \multirow{3}{*}{$\begin{array}{c}\text { Indikat } \\
\text { or }\end{array}$} & \multicolumn{5}{|c|}{ Jawaban } & \multirow{3}{*}{$\sum$} & \multirow{3}{*}{$\begin{array}{l}\text { Tota } \\
1 \\
\text { Skor }\end{array}$} & \multirow{3}{*}{$\begin{array}{c}\text { Skor } \\
\text { Idea } \\
1\end{array}$} & \multirow{3}{*}{$\begin{array}{c}\text { Persentas } \\
\text { e }\end{array}$} \\
\hline & & 1 & 2 & 3 & 4 & 5 & & & & \\
\hline & & $\begin{array}{c}\text { ST } \\
\text { S }\end{array}$ & $\begin{array}{l}\mathrm{T} \\
\mathrm{S}\end{array}$ & $\mathrm{R}$ & $S$ & SS & & & & \\
\hline 1 & X1.13 & 2 & 15 & 41 & 0 & 8 & 66 & 195 & & $59,09 \%$ \\
\hline 2 & X1.14 & 4 & 18 & 34 & 0 & 10 & 66 & 192 & 330 & $58,18 \%$ \\
\hline
\end{tabular}

Sumber: Data yang telah Diolah, 2019

a. Tanggapan responden mengenai karyawan y0ang mengikuti pelatihan sesuai dengan kualifikasi peserta pelatihan. (X1.13).

Berdasarkan tabel diatas, hasil jawaban responden untuk pernyataan tersebut adalah menjawab sangat tidak setuju 2 responden $(3,0 \%)$, tidak setuju 15 responden $(22,7 \%)$, ragu-ragu 41 responden $(62,1 \%)$, setuju 0 responden $(0 \%)$, sangat setuju 8 responden $(12,1 \%)$. Berdasarkan hal ini, pada implementasinya karyawan PT. Dahana (Persero) cukup selalu direkomendasikan untuk mengikuti setiap pelatihan dengan syarat memenuhi kualifikasi terlebih dahulu. Untuk 41 responden menjawab ragu-ragu dan 15 responden menjawab tidak setuju dapat disimpulkan dalam hal ini terlihat bahwa tidak semua atasan memberikan kebijakan kesetiap pegawai nya untuk mengikuti pelatihan.

b. Tanggapan responden mengenai karyawan semangat mengikuti program pelatihan (X1.14).

Berdasarkan tabel diatas, hasil jawaban responden untuk pernyataan tersebut adalah menjawab sangat tidak setuju 4 responden $(6,1 \%)$, tidak setuju 18 responden $(27,3 \%)$, ragu-ragu 34 responden $(51,5 \%)$, setuju 0 responden $(0 \%)$, sangat setuju 10 responden $(15,2 \%)$. Dari hasil jawaban diatas, setuju.

Pada implementasinya, karyawan di PT. Dahana (Persero) semangat dalam berpastisipasi saat di ikut sertakan mengikuti program pelatihan. Walaupun tidak seeluruhnya karyawan merasa semangat pada saat pelatihan. Untuk 34 responden menjawab ragu-ragu dan 18 responden menjawab tidak setuju dapat dikatakan bahwa tidak semua karyawan merasa semangat dalam mengikuti pelatihan. Menurut salah satu karyawan bahwa selalu ada karyawan yang tidak bersedia di 
ikuterstakan pelatihan dengan alasan berbagai faktor. PT. Dahana (Persero) sudah sering merekomendasikan pegawainya untuk mengikuti setiap pelatihan agar bertujuan untuk meningkatkan kinerja pegawainya. Veithzal Rivai (2004:240) Sangat penting untuk memperhitungkan tipe pekerja dan jenis pekerja yang akan dilatih.

Analisis Rekapitulasi Skor Variabel Pelatihan

Hasil analisis rekapitulasi skor variabel Pelatihan serta penjelasannya dapat dilihat dari Diagram sebagai berikut:

\section{Analisis Rekapitulasi Skor Variabel Pelatihan}

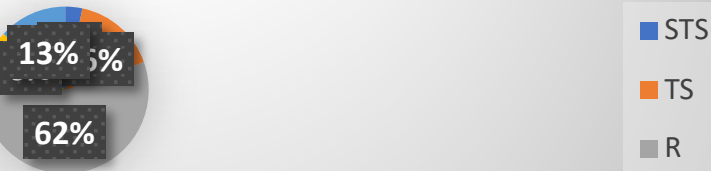

Sumber : Data yang diolah, 2019

Berdasarkan Diagram diatas, jumlah jawaban responden yang menyatakan ragu-ragu terhadap variabel pelatihan menjadi angka mayoritas yaitu sebesar 62\%, jawaban yang menyatakan tidak setuju sebesar $16 \%$, jawaban yang menyatakan setuju sebesar $6 \%$, yang menjawab sangat setuju sebesar $13 \%$, dan yang menjawab sangat tidak setuju sebesar $3 \%$.

Hasil rekapitulasi skor variabel pelatihan di atas dapat dijelaskan bahwa besarnya persentase yang menyatakan setuju menunjukkan bahwa jika pelatihan yang tepat, dapat memberikan efek yang baik kepada karyawan. Karyawan dapat mengembangkan diri dan mampu memahami seluk-beluk pelaksanaan pekerjaan lebih mendalam, dapat memahami perkembangan perusahaan, memahami sasaran yang akan dicapai perusahaan, mengerti akan perlunya kerjasama dalam melaksanakan pekerjaan, dapat dengan mudah memahami Informasi yang disampaikan perusahaan, dapat memahami setiap kesulitan-kesulitan yang dihadapi perusahaan, mampu melakukan hubungan-hubungan dengan lingkungan, mampu memahami kebijaksanaan dan peraturan yang berlaku dalam perusahaan, mampu memahami sistem dan prosedur yang digunakan dalam pelaksanaan tugas perusahaan, mampu memahami dan menerapkan perilaku yang mendukung dan dituntut perusahaan.

Untuk mengetahui seberapa besar pelatihan yang ada di PT. Dahana (Persero) Subang, dilakukan pengukuran atas kuesioner yang disebarkan dengan menyusun kriteria penilaian untuk setiap item pernyataan berdasarkan persentase dengan langkah sebagai berikut:

1. Nilai kumulatif adalah jumlah dari setiap pernyataan yang merupakan jawaban dari responden.

2. Persentase adalah nilai kumulatif item dibagi dengan nilai frekensi dikalikan $100 \%$. 
3. Menghitung jumlah kumulatif terbesar dan terkecil.

Jumlah responden adalah 66 orang dengan nilai skala pengukuran terbesar adalah 5 dan skala pengukuran terkcil adalah 1 sehingga diperoleh jumlah kumulatif terbesar $66 \times 5=330$ dan jumlah kumulatif terkeil $66 \times 1=66$.

4. Menghitung nilai persentase terbesar dan terkecil

Nialai persentase terbesar $+(330 / 330) \times 100 \%=100 \%$

Nilai persentase terkecil $=(66 / 330) \times 100 \%=20 \%$

5. Menghitung nilai rentang

Menghitung nilai rentang persentase adalah $100 \%-20 \%=80 \%$. Jika nilai rentang dibagi 5 skala pengukuran, maka akan diperoleh interval persentase sebesar $16 \%$. Selanjutnya akan dicantumkan tabel interpretasi Pelatihan dengan ketentuan sebagai berikut :

Tabel 7

Kategori Interpretasi Skor

\begin{tabular}{|c|c|}
\hline INDEKS & TINGKAT \\
\hline $20 \%-36 \%$ & Sangat Lemah \\
\hline$>36 \%-52 \%$ & Lemah \\
\hline$>52 \%-68 \%$ & Sedang \\
\hline$>68 \%-84 \%$ & Kuat \\
\hline$>84 \%-100 \%$ & Sangat Kuat \\
\hline
\end{tabular}

Sumber: Olahan penulis, 2019

Tabel 8

Interpretasi Variabel Pelatihan

$(\mathrm{N}=66)$

\begin{tabular}{|c|c|c|c|c|c|c|c|c|c|c|}
\hline \multirow{3}{*}{ Variabel } & \multicolumn{5}{|c|}{ Jawaban } & \multirow{3}{*}{$\sum$} & \multirow{3}{*}{$\begin{array}{c}\text { Skor } \\
\text { Tota } \\
1\end{array}$} & \multirow{3}{*}{$\begin{array}{c}\text { Skor } \\
\text { Idea } \\
1\end{array}$} & \multirow{3}{*}{$\begin{array}{l}\text { Perse } \\
\text { ntase }\end{array}$} & \multirow{3}{*}{ Ket. } \\
\hline & 1 & 2 & 3 & 4 & 5 & & & & & \\
\hline & $\begin{array}{c}\text { ST } \\
\text { S }\end{array}$ & TS & $\mathrm{R}$ & $S$ & SS & & & & & \\
\hline Pelatihan & 26 & $\begin{array}{c}20 \\
1\end{array}$ & $\begin{array}{l}41 \\
7\end{array}$ & $\begin{array}{c}20 \\
3\end{array}$ & 54 & 924 & 2761 & 4620 & $\begin{array}{c}59,76 \\
\%\end{array}$ & $\begin{array}{c}\text { Seda } \\
\text { ng }\end{array}$ \\
\hline
\end{tabular}

Sumber : Hasil Pengolahan Data, 2019

Berdasarkan Tabel diatas, diketahui nilai persentase intepretasi jawaban responden tentang Pelatihan sebesar 59,76\%, dimana nilai ini berada di kisaran angka $>52 \%$ $68 \%$ yang menunjukan bahwa Pelatihan di PT. Dahana (Persero) Subang berada di tingkat sedang.

Analisis Deskriptif Variabel Kinerja Karyawan

Terdapat enam indikator yang dijadikan bahan ukur terhadap Kinerja Karyawan, yaitu Kuantitas Kerja, Kualitas Kerja, Ketepatan Waktu, Efektivitas, Kemandirian, dan Komitmen. Dari keenam indikator tersebut dapat dijelaskan sebagai berikut berdasarkan hasil penelitian penulis pada saat dilapangan kemudian dikakukan analisis deskriptifnya. 


\section{Kuantitas Kerja}

Hasil jawaban responden, terdapat dua pernyataan yang berhubungan dengan indikator Kuantitas Kerja, terdapat 66 responden yang menjawab dan dapat dilihat dalam bentuk tabel sebagai berikut:

Tabel 9

Jawaban atas Pernyataan Indikator Kuantitas Kerja

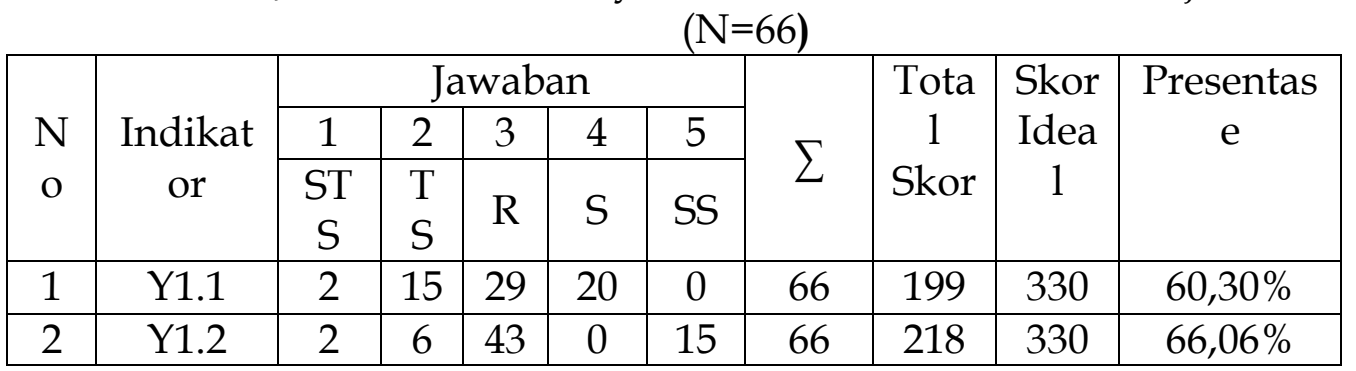

Sumber: Data yang Diolah, 2019

a. Tanggapan responden mengenai Keterampilan dan wawasan karyawan telah mempercepat waktu penyelesaian pekerjaan (Y1.1).

Berdasarkan tabel diatas, hasil jawaban responden untuk pernyataan tersebut adalah menjawab sangat tidak setuju 2 responden $(3,0 \%)$, tidak setuju 15 responden $(22,7 \%)$, ragu-ragu 29 responden $(43,9 \%)$, setuju 20 responden $(30,3 \%)$, sangat setuju 0 responden $(0 \%)$. Dari hasil jawaban diatas, ragu-ragu merupakan jawaban terbanyak mengenai Keterampilan dan wawasan karyawan sudah mempercepat waktu penyelesaian pekerjaan.

Dilihat dari banyaknya presentase tentang pernyataan di atas, dapat dijelaskan bahwa keterampilan dan wawasan karyawan masih diragukan dalam mempercepat waktu penyelesaian pekerjaan.

c. Tanggapan responden mengenai Kinerja karyawan selalu mencapai target yang ditetapkan perusahaan (Y1.2).

Berdasarkan tabel diatas, hasil jawaban responden untuk pernyataan tersebut adalah menjawab sangat tidak setuju 2 responden $(3,0 \%)$, tidak setuju 6 responden $(9,1 \%)$, ragu-ragu 43 responden $(65,2 \%)$, setuju 0 responden $(0 \%)$, sangat setuju 15 responden $(22,7 \%)$. Dari hasil jawaban diatas, ragu-ragu merupakan jawaban terbanyak mengenai Kinerja karyawan selalu mencapai target yang ditetapkan perusahaan.

Dalam hal ini bahwa para karyawan PT. Dahana (Persero) masih ragu pada pernyataan tersebut sehingga dapat disimpulkan karyawan belum sepenuhnya merasa bahwa kinerjanya selalu mencapai target yang ditetapkan perusahaan. Menurut Wungu dan Brotoharsojo (2003:56) bahwa “Quantity (kuantitas) adalah segala bentuk satuan ukuran yang terkait dengan jumlah hasil kerja dan dinyatakan dalam ukuran angka atau yang dapat dipadankan dengan angka".

Kualitas Kerja

Hasil jawaban responden, terdapat dua pernyataan yang berhubungan dengan indikator Kualitas Kerja, terdapat 66 responden yang menjawab dan dapat dilihat dalam bentuk tabel sebagai berikut: 
Tabel 4.10

Jawaban atas Pernyataan Indikator kualitas kerja

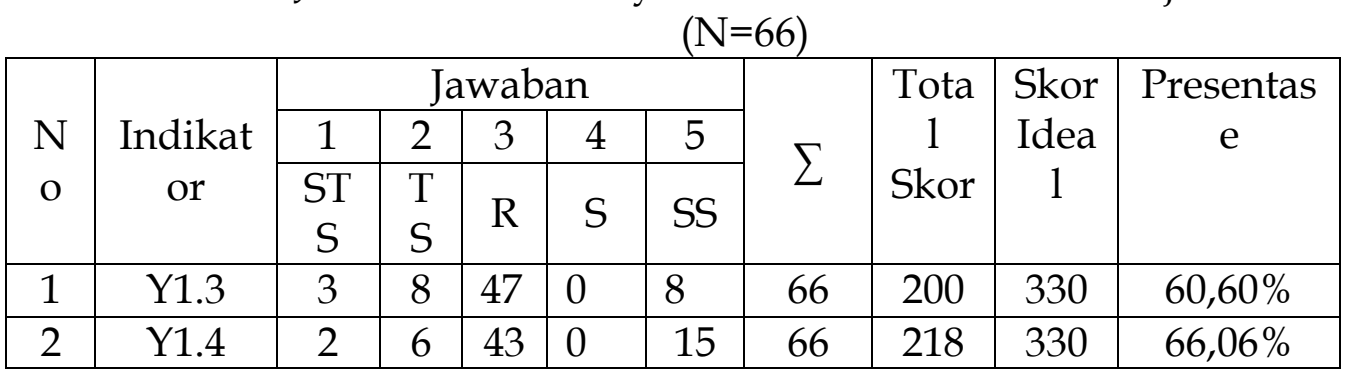

Sumber: Data yang Diolah, 2018

a. Tanggapan responden mengenai Karyawan sudah baik dalam menyelesaikan pekerjaan sesuai dengan keinginan perusahaan. (Y1.3).

Berdasarkan tabel diatas, hasil jawaban responden untuk pernyataan tersebut adalah menjawab sangat tidak setuju 3 responden $(4,5 \%)$, tidak setuju 8 responden $(12,1 \%)$, ragu-ragu 47 responden $(71,2 \%)$, setuju 0 responden $(0 \%)$, sangat setuju 8 responden $(12,1 \%)$. Dari hasil jawaban diatas, ragu-ragu merupakan jawaban terbanyak mengenai karyawan sudah baik dalam menyelesaikan pekerjaan sesuai dengan keinginan perusahaan.

Berdasarkan hasil dari tanggapan tersebut, dapat dijelaskan bahwa 71,2\% karyawan PT. Dahana (Persero) ragu-ragu dalam pelaksanaan pernyataan tersebut.

b. Tanggapan responden mengenai Karyawan sudah sangat teliti dalam bekerja (Y1.4) Berdasarkan tabel diatas, hasil jawaban responden untuk pernyataan tersebut adalah menjawab sangat tidak setuju 2 responden $(3,0 \%)$, tidak setuju 6 responden $(9,1 \%)$, ragu-ragu 43 responden $(65,2 \%)$, setuju 0 responden $(0 \%)$, sangat setuju 15 responden (22,7\%). Dari hasil jawaban diatas, ragu-ragu merupakan jawaban terbanyak mengenai Karyawan sudah sangat teliti dalam bekerja. Berdasarkan hasil jawaban responden di atas menunjukan karyawan belum sepenuhnya yakin bahwa sudah sangat teliti dalam pekerjaanya.

PT. Dahana (Persero) dalam memberikan pekerjaan terhadap para pegawai selalu melaksanakan penilaian dengan maksud untuk meningkatkan kemampuan dalam melaksanakan tugas dan kewajibannya. Hal ini dilakukan demi terciptanya suatu hasil kualitas yang memuaskan bagi perusahaan juga bagi pegawai tersebut. Kualitas kerja mengacu kualitas sumber daya manusia (Matutina,2001:205), kualitas sumber daya manusia mengacu pada: Pengetahuan (Knowledge) yaitu kemampuan yang dimiliki karyawan yang lebih berorientasi pada intelejensi dan daya fikir serta penguasaan ilmu yang luas yang dimiliki karyawan. Keterampilan (Skill), kemampuan dan penguasaan teknis operasional di bidang tertentu yang dimiliki karyawan. Abilities yaitu kemampuan yang terbentuk dari sejumlah kompetensi yang dimiliki seorang karyawan yang mencakup Kinerja, kedisiplinan, kerjasama dan tanggung jawab.

\section{Ketepatan Waktu}

Hasil jawaban responden, terdapat dua pernyataan yang berhubungan dengan indikator ketepatan waktu, terdapat 66 responden yang menjawab dan dapat dilihat dalam bentuk tabel sebagai berikut:

\section{Tabel 11}


Jawaban atas Pernyataan Indikator ketepatan waktu

\begin{tabular}{|c|c|c|c|c|c|c|c|c|c|c|}
\hline \multirow{4}{*}{$\begin{array}{c}\mathrm{N} \\
\mathrm{O}\end{array}$} & \multirow{4}{*}{$\begin{array}{c}\text { Indikat } \\
\text { or }\end{array}$} & \multirow{2}{*}{\multicolumn{5}{|c|}{ Jawaban }} & \multirow{4}{*}{$\sum$} & \multirow{4}{*}{$\begin{array}{c}\text { Tota } \\
1 \\
\text { Skor }\end{array}$} & \multirow{4}{*}{$\begin{array}{c}\text { Skor } \\
\text { Idea } \\
1\end{array}$} & \multirow{4}{*}{$\begin{array}{c}\text { Presentas } \\
\text { e }\end{array}$} \\
\hline & & & & & & & & & & \\
\hline & & 1 & 2 & 3 & 4 & 5 & & & & \\
\hline & & $\begin{array}{c}\text { ST } \\
\text { S }\end{array}$ & $\begin{array}{l}\mathrm{T} \\
\mathrm{S}\end{array}$ & $\mathrm{R}$ & $S$ & SS & & & & \\
\hline 1 & Y1.5 & 3 & 8 & 47 & 0 & 8 & 66 & 200 & 330 & $60,60 \%$ \\
\hline & Y1.6 & 1 & 12 & 40 & 12 & 1 & 66 & 251 & 330 & $76,06 \%$ \\
\hline
\end{tabular}

Sumber: Data yang Diolah, 2019

a. Tanggapan responden mengenai Ketepatan dalam waktu menyelesaikan pekerjaan karyawan sudah sesuai standar perusahaan (Y1.5).

Berdasarkan tabel diatas, hasil jawaban responden untuk pernyataan tersebut adalah menjawab sangat tidak setuju 3 responden $(4,5 \%)$, tidak setuju 8 responden $(12,1 \%)$, ragu-ragu 47 responden $(71,2 \%)$, setuju 0 responden $(0 \%)$, sangat setuju 8 responden $(12,1 \%)$. Dari hasil jawaban diatas, ragu-ragu merupakan jawaban terbanyak mengenai Karyawan sudah sangat teliti dalam bekerja. Dalam hal ini, dapat dijelaskan bahwa pegawai PT. Dahana (Persero) dalam pengerjaan tugas yang diberikan masih memerlukan pelatihan agar dapat memanfaatkan waktu semaksimal mungkin dalam penyelesaian tugas tersebut.

b. Tanggapan responden mengenai Tepat dalam rencana kerja yang dituntut perusahaan dengan hasil kerja karyawan (Y1.6).

Berdasarkan tabel diatas, hasil jawaban responden untuk pernyataan tersebut adalah menjawab sangat tidak setuju 1 responden $(1,5 \%)$, tidak setuju 12 responden $(18,2 \%)$, ragu-ragu 40 responden $(60,6 \%)$, setuju 12 responden $(18,2 \%)$, sangat setuju 1 responden $(1,5 \%)$. Dari hasil jawaban diatas, ragu-ragu merupakan jawaban terbanyak mengenai Tepat dalam rencana kerja yang dituntut perusahaan dengan hasil kerja karyawan. Dalam hal ini, dapat dijelaskan bahwa pegawai PT. Dahana (Persero) dalam memberikan tugas atau suatu pekerjaan selalu menekankan terhadap pegawai agar tepat waktu dalam rencana kerja yang dituntut perusahaan dengan hasil kerja karyawan. Menurut Hasibuan (2008:94) kinerja adalah suatu hasil kerja yang dicapai seseorang dalam melaksanakan tugas yang dibebankan yang di dasarkan atas kecakapan, pengalaman dan kesungguhan, serta waktu.

\section{Efektivitas}

Hasil jawaban responden, terdapat dua pernyataan yang berhubungan dengan indikator Efektivitas, terdapat 66 responden yang menjawab dan dapat dilihat dalam bentuk tabel sebagai berikut:

Tabel 12

Jawaban atas Pernyataan Indikator Efektivitas

$$
(\mathrm{N}=66)
$$

\begin{tabular}{|c|c|c|c|c|c|c|c|c|c|c|}
\hline \multirow{3}{*}{$\begin{array}{l}\mathrm{N} \\
\mathrm{O}\end{array}$} & \multirow{3}{*}{$\begin{array}{c}\text { Indikat } \\
\text { or }\end{array}$} & \multicolumn{5}{|c|}{ Jawaban } & \multirow{3}{*}{$\sum$} & \multirow{3}{*}{$\begin{array}{c}\text { Tota } \\
1 \\
\text { Skor }\end{array}$} & \multirow{3}{*}{$\begin{array}{c}\text { Skor } \\
\text { Idea } \\
1\end{array}$} & \multirow{3}{*}{$\begin{array}{c}\text { Presentas } \\
\text { e }\end{array}$} \\
\hline & & 1 & 2 & 3 & 4 & 5 & & & & \\
\hline & & $\begin{array}{c}\text { ST } \\
\text { S }\end{array}$ & $\begin{array}{l}\mathrm{T} \\
\mathrm{S}\end{array}$ & $\mathrm{R}$ & $S$ & SS & & & & \\
\hline 1 & Y1.7 & 4 & 18 & 34 & 0 & 10 & 66 & 192 & 330 & $58,18 \%$ \\
\hline
\end{tabular}




\section{\begin{tabular}{|l|l|l|l|l|l|l|l|l|l|l|}
2 & Y1.8 & 1 & 6 & 38 & 0 & 21 & 66 & 232 & 330 & $70,30 \%$ \\
\hline
\end{tabular}}

Sumber: Data yang diolah, 2019

a. Tanggapan responden mengenai Efisien dalam penggunaan sumberdaya organisasi dan menaikan hasil setiap unit dalam penggunaan sumberdaya perusahaan (Y7).

Berdasarkan tabel diatas, hasil jawaban responden untuk pernyataan tersebut adalah menjawab sangat tidak setuju 4 responden $(6,1 \%)$, tidak setuju 18 responden $(27,3 \%)$, ragu-ragu 34 responden $(51,5 \%)$, setuju 0 responden $(0 \%)$, sangat setuju 10 responden $(15,2 \%)$. Dari hasil jawaban diatas, ragu-ragu merupakan jawaban terbanyak mengenai Efisien dalam penggunaan sumberdaya organisasi dan menaikan hasil setiap unit dalam penggunaan sumberdaya perusahaan. Hal tersebut menunjukan bahwa karyawan merasa belum sepenuhnya dalam peningkatan efisiensi dalam penggunaan sumberdaya dan menaikan hasil setiap unit dalam penggunaan sumberdaya.

c. Tanggapan responden mengenai Kemampuan karyawan baik dalam membuat rencana pekerjaan sehingga tercapai efisiensi dan efektivitas (Y1.8).

Berdasarkan tabel 4.18, hasil jawaban responden untuk pernyataan tersebut adalah menjawab sangat tidak setuju 1 responden $(1,5 \%)$, tidak setuju 6 responden $(9,1 \%)$, ragu-ragu 38 responden $(57,6 \%)$, setuju 0 responden $(0 \%)$, sangat setuju 21 responden $(31,8 \%)$. Dari hasil jawaban diatas, ragu-ragu merupakan jawaban terbanyak mengenai Kemampuan karyawan baik dalam membuat rencana pekerjaan sehingga tercapai efisiensi dan efektivitas.

Berdasarkan hasil dari tanggapan tersebut, kemampuan karyawan pada PT. Dahana (Persero) masih memerlukan peningkatan dalam membuat rencana kerja agar tercapai efisiensi dan efektivitas. Miranda (2003:82) menyatakan bahwa efisiensi adalah prediksi keluaran/output pada biaya minimum, atau merupakan rasio antara kuantitas sumber yang digunakan dengan keluaran yang dikirim.

\section{Kemandirian}

Hasil jawaban responden, terdapat dua pernyataan yang berhubungan dengan indikator Kemandirian, terdapat 66 responden yang menjawab dan dapat dilihat dalam bentuk tabel sebagai berikut:

Tabel 12

Jawaban atas Pernyataan Indikator kemandirian

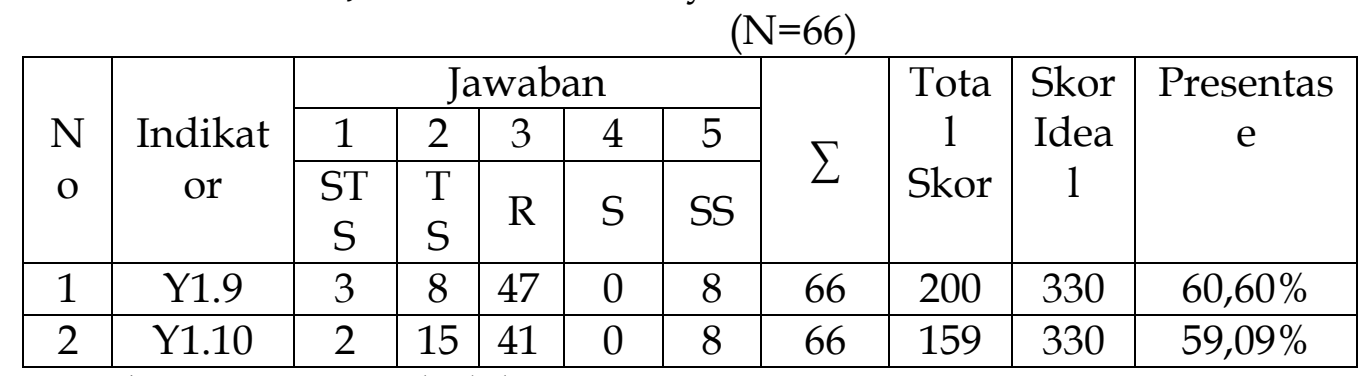

Sumber: Data yang diolah, 2019

a. Tanggapan responden mengenai Kemandirian karyawan dalam melaksanakan fungsi kerja tanpa harus meminta bantuan pengawasan untuk mencegah hasil yang merugikan. (Y1.9). 
Berdasarkan tabel diatas, hasil jawaban responden untuk pernyataan tersebut adalah menjawab sangat tidak setuju 3 responden $(4,5 \%)$, tidak setuju 8 responden $(12,1 \%)$, ragu-ragu 47 responden $(71,2 \%)$, setuju 0 responden $(0 \%)$, sangat setuju 8 responden $(12,1 \%)$. Dari hasil jawaban diatas, ragu-ragu merupakan jawaban terbanyak mengenai Kemandirian karyawan dalam melaksanakan fungsi kerja tanpa harus meminta bantuan pengawasan untuk mencegah hasil yang merugikan. Hal tersebut menunjukan bahwa karyawan PT. Dahana (Persero) kurang dapat menyelesaikan masalah yang timbul ketika dalam melaksanakan sebuah pekerjaan yang diberikan tanpa harus meminta bantuan pengawasan untuk mencegah hasil yang merugikan. Maka dari itu karyawan setuju pada pernyataan tersebut.

b. Tanggapan responden mengenai Karyawan inisiatif dalam menyelesaikan pekerjaannya (Y1.10).

Berdasarkan tabel diatas, hasil jawaban responden untuk pernyataan tersebut adalah menjawab sangat tidak setuju 2 responden $(3,0 \%)$, tidak setuju 15 responden $(22,7 \%)$, ragu-ragu 41 responden $(62,1 \%)$, setuju 0 responden $(0 \%)$, sangat setuju 8 responden $(12,1 \%)$. Dari hasil jawaban diatas, ragu-ragu merupakan jawaban terbanyak mengenai Karyawan inisiatif dalam menyelesaikan pekerjaannya. Berdasarkan hasil dari tanggapan tersebut, karyawan PT. Dahana (Persero) dalam mengerjakan pekerjaan kurang mampu meminimalkan timbulnya masalah atau kesalahan yang dapat menghambat penyelesaian pekerjaan tersebut.

PT. Dahana (Persero) dalam kegiatannya, selalu menjadwalkan waktu untuk dapat mendiskusikan permasalahan yang ada dengan secara terbuka. Hal ini dilakukan oleh perusahaan guna mendapatkan informasi penting dari setiap pegawai dalam memberikan masukan untuk mengangani permasalahan yang ada sekaligus dilakukan untuk meningkatkan inisiatif dan keandalan yang dimiliki oleh setiap pegawai. Menurut Masrun (1986:155) kemandirian adalah suatu sikap yang memungkinkan seseorang untuk bertindak bebas, melakukan sesuatu atas dorongan sendiri dan untuk kebutuhannya sendiri tanpa bantuan dari orang lain, maupun berfikir dan bertindak original, kreatif, penuh inisiatif, dan mampu mempengaruhi lingkungan, mempunyai rasa percaya diri, dan memeperoleh kepuasan dari usahanya.

\section{Komitmen}

Hasil jawaban responden, terdapat dua pernyataan yang berhubungan dengan indikator Komitmen, terdapat 66 responden yang menjawab dan dapat dilihat dalam bentuk tabel sebagai berikut:

Tabel 13

Jawaban atas Pernyataan Indikator komitmen

\begin{tabular}{|c|c|c|c|c|c|c|c|c|c|c|}
\hline & \multicolumn{10}{|c|}{$(\mathrm{N}=66)$} \\
\hline \multirow{3}{*}{$\begin{array}{l}\mathrm{N} \\
\mathrm{O}\end{array}$} & \multirow{3}{*}{$\begin{array}{c}\text { Indikat } \\
\text { or }\end{array}$} & \multicolumn{5}{|c|}{ Jawaban } & \multirow{3}{*}{$\sum$} & \multirow{3}{*}{$\begin{array}{c}\text { Tota } \\
1 \\
\text { Skor }\end{array}$} & \multirow{3}{*}{$\begin{array}{c}\text { Skor } \\
\text { Idea } \\
1\end{array}$} & \multirow{3}{*}{$\begin{array}{c}\text { Presentas } \\
\text { e }\end{array}$} \\
\hline & & 1 & 2 & 3 & 4 & 5 & & & & \\
\hline & & $\begin{array}{c}\text { ST } \\
\text { S }\end{array}$ & $\begin{array}{l}\mathrm{T} \\
\mathrm{S}\end{array}$ & $\mathrm{R}$ & $S$ & SS & & & & \\
\hline 1 & Y1.11 & 4 & 18 & 34 & 0 & 10 & 66 & 192 & 330 & $58,18 \%$ \\
\hline 2 & Y1.12 & 5 & 8 & 39 & 14 & 0 & 66 & 194 & 330 & $58,78 \%$ \\
\hline
\end{tabular}

Sumber: Data yang diolah, 2019 
a. Tanggapan responden Rasa tanggung jawab dari karyawan terhadap tugas dan kewajibannya pada perusahaan (Y1.11).

Berdasarkan tabel diatas, hasil jawaban responden untuk pernyataan tersebut adalah menjawab sangat tidak setuju 4 responden $(6,1 \%)$, tidak setuju 18 responden $(27,3 \%)$, ragu-ragu 34 responden $(51,1 \%)$, setuju 0 responden $(0 \%)$, sangat setuju 10 responden $(15,2 \%)$. Dari hasil jawaban diatas, ragu-ragu merupakan jawaban terbanyak mengenai Rasa tanggung jawab dari karyawan terhadap tugas dan kewajibannya pada perusahaan. Berdasarkan hasil dari tanggapan tersebut, dapat dijelaskan 51,1\% ragu-ragu dengan pernyataan tersebut bahwa karyawan PT. Dahana (Persero) masih harus meningkatkan rasa bangga dan tanggung jawab serta selalu berusaha memberikan kemampuan terbaiknya pada perusahaan dan harus selalu mendahulukan kepentingan perusahaan.

b. Tanggapan responden mengenai Karyawan mampu berkerjasama dan membangun kinerja tim yang baik (Y1.12).

Berdasarkan tabel diatas, hasil jawaban responden untuk pernyataan tersebut adalah menjawab sangat tidak setuju 5 responden $(7,6 \%)$, tidak setuju 8 responden $(12,1 \%)$, ragu-ragu 39 responden $(59,1 \%)$, setuju 14 responden $(21,2 \%)$, sangat setuju 0 responden $(0 \%)$. Dari hasil jawaban diatas, ragu-ragu merupakan jawaban terbanyak mengenai pernyataan Karyawan mampu berkerjasama dan membangun kinerja tim yang baik. Berdasarkan hasil dari tanggapan tersebut, bahwa karyawan PT. Dahana (Persero) perlu mengikuti sebuah program yang dapat meningkatkan kemampuan kerjasama karyawan serta membangun kinerja tim yang baik. Menurut Hasibuan (2005:175) komitmen yaitu kesanggupan suatu karyawan atau anggota organisasi untuk tetap memelihara sebuah nilai dalam upaya pencapaian tujuan organisasi secara umum.

\section{Analisis Rekapitulasi Skor Variabel Kinerja Karyawan}

Hasil analisis rekapitulasi skor variabel Kinerja Karyawan serta penjelasannya dapat dilihat dari Diagram sebagai berikut:

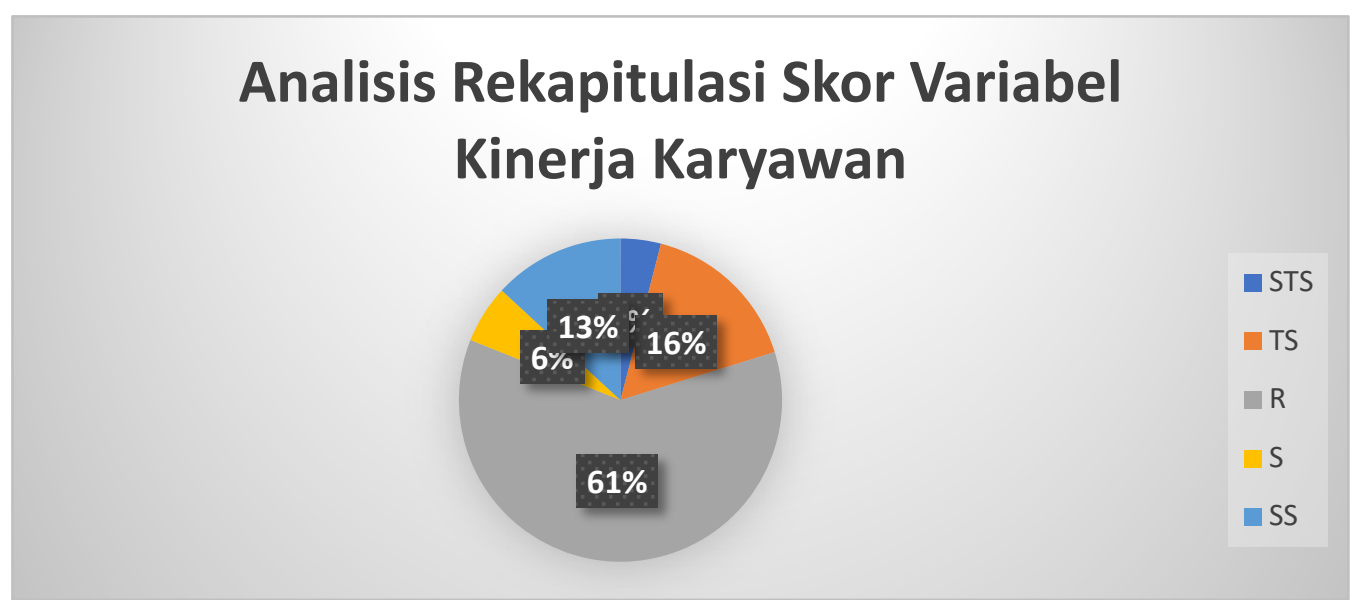

Sumber : Data yang diolah, 2019

Berdasarkan Diagram diatas, jumlah jawaban responden yang menyatakan ragu-ragu terhadap variabel Kinerja Karyawan menjadi angka mayoritas yaitu sebesar $61 \%$, jawaban yang menyatakan sangat setuju sebesar $13 \%$, jawaban setuju sebesar $6 \%$, 
yang menjawab tidak setuju sebesar $16 \%$, dan yang menjawab sangat tidak setuju sebesar $4 \%$. Untuk mengetahui seberapa besar pelatihan yang ada di PT. Dahana (Persero) Subang, dilakukan pengukuran atas kuesioner yang disebarkan dengan menyusun kriteria penilaian untuk setiap item pernyataan berdasarkan persentase dengan langkah sebagai berikut:

1. Nilai kumulatif adalah jumlah dari setiap pernyataan yang merupakan jawaban dari responden.

2. Persentase adalah nilai kumulatif item dibagi dengan nilai frekensi dikalikan $100 \%$.

3. Menghitung jumlah kumulatif terbesar dan terkecil.

Jumlah responden adalah 66 orang dengan nilai skala pengukuran terbesar adalah 5 dan skala pengukuran terkcil adalah 1 sehingga diperoleh jumlah kumulatif terbesar $66 \times 5=330$ dan jumlah kumulatif terkeil $66 \times 1=66$.

4. Menghitung nilai persentase terbesar dan terkecil

Nialai persentase terbesar $+(330 / 330) \times 100 \%=100 \%$

Nilai persentase terkecil $=(66 / 330) \times 100 \%=20 \%$

5. Menghitung nilai rentang

Menghitung nilai rentang persentase adalah $100 \%-20 \%=80 \%$. Jika nilai rentang dibagi 5 skala pengukuran, maka akan diperoleh interval persentase sebesar $16 \%$.

Selanjutnya akan dicantumkan tabel interpretasi Pelatihan dengan ketentuan sebagai berikut :

Tabel 14

Kategori Interpretasi Skor

\begin{tabular}{|c|c|}
\hline INDEKS & TINGKAT \\
\hline $20 \%-36 \%$ & Sangat Lemah \\
\hline$>36 \%-52 \%$ & Lemah \\
\hline$>52 \%-68 \%$ & Sedang \\
\hline$>68 \%-84 \%$ & Kuat \\
\hline$>84 \%-100 \%$ & Sangat Kuat \\
\hline
\end{tabular}

Sumber: Olahan penulis, 2019

Tabel 15

Interpretasi Variabel Kinerja Karyawan

$(\mathrm{N}=66)$

\begin{tabular}{|c|c|c|c|c|c|c|c|c|c|c|}
\hline \multirow{3}{*}{ Variabel } & \multicolumn{5}{|c|}{ Jawaban } & \multirow{3}{*}{$\sum$} & \multirow{3}{*}{$\begin{array}{c}\text { Skor } \\
\text { Tota } \\
1\end{array}$} & \multirow{3}{*}{$\begin{array}{c}\text { Skor } \\
\text { Idea } \\
1\end{array}$} & \multirow{3}{*}{$\begin{array}{l}\text { Perse } \\
\text { ntase }\end{array}$} & \multirow{3}{*}{ Ket. } \\
\hline & 1 & 2 & 3 & 4 & 5 & & & & & \\
\hline & $\begin{array}{c}\text { ST } \\
\text { S }\end{array}$ & TS & $\mathrm{R}$ & $S$ & SS & & & & & \\
\hline $\begin{array}{c}\text { Kinerja } \\
\text { Karyawan }\end{array}$ & 32 & $\begin{array}{c}12 \\
8\end{array}$ & $\begin{array}{c}48 \\
2\end{array}$ & 46 & $\begin{array}{c}10 \\
4\end{array}$ & 792 & 2438 & 3960 & $\begin{array}{c}61,56 \\
\%\end{array}$ & Kuat \\
\hline
\end{tabular}

Sumber : Hasil Pengolahan Data, 2019

Berdasarkan Tabel diatas, diketahui nilai persentase intepretasi jawaban responden tentang Kinerja Karyawan sebesar $61,56 \%$, dimana nilai ini berada di kisaran angka $>68 \%$ - 84\% yang menunjukan bahwa Kinerja Karyawan di PT. Dahana (Persero) Subang berada di tingkat kuat. 
Pengaruh Pelatihan terhadap Kinerja Karyawan di PT. Dahana (Persero) Subang Berdasrakan Hasil penelitian yang dilakukan, dapat diproleh gambaran bahwa pengaruh Variabel $X$ terhadap $Y$ telah sesuai dengan hipotesis yang telah dikemukakan. Pelatihan yang diukur dengan Tujuan, Sasaran, Pelatih, Materi, Metode, dan Peserta. Pelatihan berpengaruh terhadap Kinerja karyawan yang diukur dengan Kuantitas kerja, Kualitas kerja, Ketepatan waktu, Efektivitas, Kemandirian, dan Komitmen. Berdasarkan perhitungan, maka diperoleh hasil bahwa terdapat antara Pelatihan terhadap Kinerja karyawan di PT. Dahana (Persero) Subang. Berdasarkan hasil perhitungan SPSS 18 menunjukan bahwa adanya pengaruh antara variabel Pelatihan $(X)$ terhadap variabel Kinerja Karyawan (Y) dengan hasil perhitungan $\mathrm{R}$ square sebesar 0,568 atau $0,568 \times 100 \%=56,8 \%$ yang berarti bahwa variabel independen (Pelatihan) mempengaruhi variabel dependen (Kinerja Karyawan) sebesar 56,8\% dan sisanya sebesar 43,2\% yang diperkirakan dipengaruhi oleh faktor lain seperti faktor kepuasan kerja, upah, personal, motivasi, kontekstual dan sebagainya. Namun, faktor tersebut tidak diteliti lebih lanjut oleh peneliti melainkan dapat diteliti oleh peneliti lain sebagai acuan untuk diteliti dan dikembangkan lagi.

Hal ini berarti bahwa terdapat pengaruh Pelatihan terhadap Kinerja karyawan di PT. Dahana (Persero) Subang. Bisa dikatakan apabila Pelatihan semakin tinggi maka Kinerja Karyawan akan meningkat. Sebaliknya apabila Pelatihan semakin berkurang maka Kinerja karyawan akan mengalami penurunan. Dengan demikian, hal ini menunjukan bahwa pelaksanaan Pelatihan berpengaruh terhadap Kinerja Karyawan pada PT. Dahana (Persero) Subang. Hal ini pun diperkuat dengan yang telah di kemukakan oleh Veithzal Rivai (2011:227) bahwa "Walaupun pelatihan dapat membantu karyawan untuk mengerjakan pekerjaan untuk saat ini, keuntungan dari pelatihan dapat diperoleh sepanjang karirnya dan dapat membantu peningkatan karirnya di masa mendatang.

\section{Kesimpulan}

Sesuai dengan tujuan penelitian yang telah direncanakan penulis yaitu untuk mengetahui adakah pengaruh Pelatihan terhadap Kinerja karyawan di PT. Dahana (Persero) Subang. Penulis telah melakukan pengolahan data, pengujian hipotesis, dan analisis data dari hasil survey 66 responden yaitu pegawai PT. Dahana (Persero) Subang. Maka penulis dapat menyimpulkan:

1. Pelatihan pada PT. Dahana (Persero) Subang yang diukur berdasarkan enam indikator yakni Tujuan, Sasaran, Pelatih, Materi, Metode, dan Peserta dilihat dari nilai persentase intepretasi jawaban responden tentang Pelatihan sebesar $59,76 \%$, dimana nilai ini berada di kisaran angka $>52 \%-68 \%$ yang menunjukan bahwa Pelatihan di PT. Dahana (Persero) Subang berada di taraf tingkat sedang. Yang berarti PT. Dahana (Persero) telah mengikuti langkah-langkah program pelatihan sesuai yang ditetapkan perusahaan namun masih ada indikatorindikator yang belum maksimal dilihat dari presentase hasil jawaban pada indikator sasaran yang dimana nilai hasil presentase nya dibawah indikatorindikator lain.

2. Kinerja Karyawan pada PT. Dahana (Persero) Subang yang juga diukur berdasarkan enam indikator yaitu Kuantitas, Kualitas, Ketepatan Waktu, 
Efektivitas, Kemandirian, dan Komitmen jika dilihat dari nilai persentase intepretasi jawaban responden tentang Kinerja Karyawan sebesar 61,56\%, dimana nilai ini berada di kisaran angka $>68 \%$ - 84\% yang menunjukan bahwa Kinerja Karyawan di PT. Dahana (Persero) Subang berada di taraf tingkat kuat.

3. Pelatihan berpengaruh terhadap Kinerja karyawan PT. Dahana (Persero) dengan nilai positif. Ketika Pelatihan semakin tinggi maka Kinerja Karyawan akan meningkat. Namun apabila Pelatihan semakin berkurang maka Kinerja karyawan akan mengalami penurunan.

Penyelenggaraan program pelatihan kerja di PT. Dahana (Persero) Subang cukup optimal. Dan outputnya telah sampai ke para karyawan PT. Dahana (Persero) Subang.

\section{Referensi}

A.A. Anwar Prabu Mangkunegara. 2009. Manajemen Sumber Daya Manusia. Bandung: PT. Remaja Rosdakarya.

Anwar Prabu Mangkunegara, 2001. Manajemen Sumber Daya Perusahaan, Bandung:PT. Remaja Rosdakarya.

Allen, Louis. 1958. A Management and Organization. New York : McGraw-. Hill Book Company.

Alma, Buchari. 2013. Manajemen Pemasaran dan Pemasaran Jasa. Bandung: Alfabeta.

Agusta, Leonando dan Sutanto, E.M. 2013. "Pengaruh Pelatihan dan motivasikerja terhadap kinerja karyawan CV Haragon Surabaya". Jurnal AGORA, Vol.1, No.3. Zainal, Veithzal Rivai, dkk. 2014. Manajemen Sumber Daya Manusia Untuk Perusahaan Dari Teori Ke Praktik. Depok. PT Rajagrafindo Persada.

Arikunto, Suharsimi. 1996. Prosedur Penelitian Suatu Pendekatan Praktik. Edisi Revisi. Jakarta: Rineka Cipta.

Anwar Prabu Mangkunegara. 2015. Sumber Daya Manusia Perusahaan. Cetakan kedua belas. Remaja Rosdakarya:Bandung.

Dessler, Gary. 2010. Manajemen Sumber Daya Manusia (edisi kesepuluh). Jakarta Barat: PT Indeks.

Fahmi, Irham, (2015) Pengantar Manajemen Keuangan Teori dan Soal Jawab. Bandung: Alfabeta.

Fahmi, Irham. 2014. Analisis Laporan Keuangan. Bandung: Alfabeta.

Hariandja, Marihot T.E, 2002. Manajemen Sumber Daya Manusia. Jakarta: Grasindo.

Hasibuan, Malayu. 2008. Manajemen Dasar, Pengertian, Dan Masalah. Jakarta: PT Bumi Aksara.

Herman Sofyandi, 2008, Manajemen Sumber Daya Manusia, Edisi Pertama,. Penerbit Graha Ilmu, Yogyakarta. 
Kandou, Emilia. 2014. Pengaruh Pelatihan dan dan Pengembangan Karyawan Terhadap Produktivitas Kerja Karyawan PT. Air Manado. Fakultas Ekonomi. Program Studi Manajemen. Universitas Klabat Manado.

Mangkuprawira, Syafry. 2002. Manajemen Sumber Daya Manusia. Strategi. Jakarta : Ghalia Indonesia.

Mangkuprawira, T. B. 2004. Manajemen SDM Strategik. Jakarta: PT Gahlia. Indonesia.

Mathis, R.L. \& J.H. Jackson. 2006. Human Resource Management: Manajemen Sumber Daya Manusia. Terjemahan Dian Angelia. Jakarta: Salemba Empat

Nawawi, Ismail, 2009. Perilaku Administrasi, Kajian Paradigma, Konsep, Teoridan Pengantar Praktik. Surabaya: ITS Press.

Rivai, Veithzal. 2009. Manajemen Sumber Daya Manusia Untuk PerusahaanDari Teori ke Praktik. Jakarta: Raja Grafindo Persada.

Rachmawati, Wati. 2016. Pengaruh Pelatihan dan Motivasi Kerja Terhadap Kinerja Karyawan PT. Bank BJB Kantor Cabang Suci Bandung. Program Studi Manajemen. Sekolah Tinggi Ilmu Ekonomi Bandung.

Samsudin, Sadili. 2010. Manajemen Sumber Daya Manusia. Bandung : Pustaka Setia.

Sinambela, Litjan Poltak, dkk. 2011. Reformasi Pelayanan Publik: Teori, Kebijakan,dan Implementasi. Jakarta: PT Bumi Aksara.

Veithzal Rivai, 2004, “Manajemen Sumber Daya Manusia Untuk Perusahaan, Cetakan Pertama, Jakarta, PT. Raja GrafindoPersada. 